\title{
¿POR QUÉ LAS MUJERES CON CÁNCER DE MAMA DEBEN ESTAR GUAPAS Y LOS HOMBRES CON CÁNCER DE PRÓSTATA PUEDEN IR SIN AFEITAR? ONCOLOGÍA, DISIDENCIA Y CULTURA HEGEMÓNICA
}

\author{
WHY DO WOMEN WITH BREAST CANCER SHOULD BE BEAUTIFUL AND MEN \\ WITH PROSTATE CANCER CAN GO WITHOUT SHAVING? ONCOLOGY, DISSENT, \\ AND HEGEMONIC CULTURE
}

\author{
Enric C. Sumalla', Vanessa Castejón ${ }^{1,3}$, Cristian Ochoa ${ }^{2}$, Ignacio Blanco \\ 1 Unidad de Consejo Genético, Programa de Cáncer Hereditario, Institut Català d'Oncologia, ICO_IDIBELL. \\ 2 Unidad de Psico-Oncología. Institut Català d'Oncologia, ICO_IDIBELL. \\ ${ }_{3}^{3}$ Departamento de Psicología Básica, Evolutiva y Educación. Facultad de Psicología. Universidad Autónoma de \\ Barcelona, España.
}

Resumen

El universo oncológico, aparentemente, constituye un ámbito de profundos consensos; aliviar el sufrimiento de pacientes y familias, la búsqueda de una cura efectiva o erradicar el estigma asociado al diagnóstico son objetivos que generan un amplio acuerdo social. Desde una perspectiva cultural, sin embargo, se constata la presencia de ciertas áreas de tensión y disidencia en torno al cáncer. En este artículo, aplicando conceptos analíticos de Gramsci y Foucault, se define en forma de decálogo lugares comunes que como el pensamiento positivo, la feminidad, la prevención o el espíritu de lucha conforman una cultura hegemónica en cáncer de mama enfrentada a los discursos de culturas subalternas como la feminista o ambientalista. Frente a la idea de unidad y consenso, el análisis de la literatura antropológica proporciona una imagen compleja donde la vivencia del cáncer, resignificando la enfermedad como un espacio de conflicto ideológico, es construida en términos de lucha de intereses y proyectos de control social.

Palabras clave: Antropología médica, cáncer de mama, cultura hegemónica, movimientos sociales, identidad de superviviente.
Abstract

The oncology universe apparently is an area of deep consensus; alleviate the suffering of patients and families, the search for an effective cure or eradicate the stigma associated with the diagnosis are objectives that generate broad societal agreement. From a cultural perspective, however, we note the presence of certain areas of tension and dissent around the cancer. In this paper, applying analytical concepts of Gramsci and Foucault, as defined Decalogue common places like positive thinking, femininity, preventing or fighting spirit form a hegemonic culture in facing breast cancer cultures speeches subaltern as feminist or environmentalist. Faced with the idea of unity and consensus, the analysis of the anthropological literature provides a complex picture where the cancer experience resignifying disease as a space of ideological conflict, is constructed in terms of conflict of interests and projects of social control.

Keywords: Medical anthropology, breast cancer, cultural hegemony, social movements, and survivor identity.

\section{Correspondencia:}

Ignacio Blanco.

Unidad de Consejo Genético, Programa de Cáncer Hereditario

Institut Català d'Oncologia, ICO_IDIBELL

Av. Gran Via de L'Hospitalet, 199-203 - 08908 L'Hospitalet. Barcelona

E-mail: iblanco@iconcologia.net 


\section{INTRODUCCIÓN. DE LO PERSONAL Y LO POLÍTICO}

En su discurso sobre el Estado de la Nación de 1971 Richard Nixon realizó un dramático Ilamamiento al pueblo americano: "Ha llegado el momento en que el mismo esfuerzo intenso que nos ha permitido dividir el átomo o situar un hombre en la Luna se dirija a conquistar esta terrible enfermedad Ilamada cáncer"(1). El 23 de diciembre de ese mismo año el presidente firmaba la National Cancer Act, conocida popularmente como War on Cancer, uno de los primeros intentos sistemáticos por dotar de sustanciosos fondos federales a programas destinados a descubrir una cura de la enfermedad. Ante un descalabro en Vietnam que dejaría a las clases dirigentes de los EUA huérfanas de enemigos, el gobierno norteamericano proponía derrotar al cáncer con el objetivo de recuperar cierta cohesión social tras las tensiones derivadas de su fallida intervención en el sudeste asiático. $\mathrm{Y}$ es que el discurso de Nixon, recogiendo una antigua tradición, presentaba características semejantes a los fenómenos de cruzada, movimientos de afán aglutinador; definía sin matices al enemigo, al infiel, en términos de una maldad absoluta a erradicar y, más importante, involucraba en la batalla a toda la nación, a toda la comunidad de creyentes. Cada uno de los ciudadanos americanos, prescindiendo de su edad, sexo o condición, debían realizar su contribución a la lucha contra el cáncer, un adversario que solo podría ser vencido desde el consenso más absoluto y la más fanática de las determinaciones.

Sin embargo, durante esos años de llamada al consenso, no dejaban de producirse molestas tensiones y desacuerdos que comprometían la unidad de propósito de la "cruzada" anticáncer de Nixon. En junio de 1974 la periodista free-lance Rose Kushner (1929-1990) fue diagnosticada de un tumor en su pecho izquierdo ${ }^{(2)}$. En ese momento, el tratamiento estándar en cáncer de mama consistía en el denominado one-steep procedure, es decir, se realizaba una biopsia quirúrgica del tejido tumoral y, en función de los resultados, se procedía inmediatamente a la extirpación del tumor, en una mayoría de casos mediante la técnica de mastectomía radical de Halsted ${ }^{(3)}$. Kushner manifestó su intención de, tras realizarse la biopsia, ser reanimada de la anestesia para poder participar en la toma de decisión sobre cuál era el tratamiento más aconsejable en su caso particular. La reacción de la American Cancer Sociaty (ACS) fue rotunda; absolutamente nadie, ni la administración mediante la instauración de protocolos clínicos ni las pacientes manifestando sus preferencias, debía coartar la plena y absoluta libertad del doctor a la hora de tomar decisiones, entendiendo que cualquier interferencia era un ataque directo a los profesionales de la cirugía que causaría grave daño a las afectados por cáncer. Tras años de activismo y batallas legales, la conferencia del National Institutes of Health $(\mathrm{NIH})$ celebrada en 1979 consensuó por fin que la mastectomía radical y el one-steep procedure no eran técnicas adecuadas ante la existencia de cirugías menos invasivas que, combinadas con radio y quimioterapia, proporcionaban índices de supervivencia equivalentes o superiores reduciendo los problemas post-quirúrgicos. De esta forma Rose Kushner pasó a constituir uno de los primeros referentes en el activismo anticáncer, un referente pero que generó gran ambivalencia; cuando la National Cancer Act reclamaba la unidad de todos en la lucha contra la enfermedad, Kushner se desmarcaba radicalmente del consenso afirmando que junto a ese enemigo Ilamado cáncer habían otros "enemigos" a combatir, una inquietante administración médica que sometía a las mujeres a un régimen terapéutico que provocaba graves 
e innecesarios sufrimientos ${ }^{(4)}$. Quedaba así definitivamente dañado uno de los puntales que justificaba la "cruzada" anticáncer de Nixon, la idea que todos y cada uno de nosotros estábamos dispuestos a comprometernos en la batalla, que los objetivos y métodos definidos por nuestros médicos y gobernantes generaban un consenso absoluto entre la población. La presencia de Kushner redefinió el campo oncológico como una área de confrontación ideológica, es decir, reforzó la idea según la cual incluso en un ámbito tan monolítico como el cáncer pueden distinguirse distintos grupos y actores con intereses contradictorios que se relacionaban entre sí en términos de conflicto. Que el cáncer, en suma, planteaba un debate y una lucha política indiscutible.

Este componente ideológico, manifestado en forma de confrontación política, subyace explícito en episodios centrales del activismo anticáncer americano. Por ejemplo, con la creación de la National Breast Cancer Coaliton (NBCC) en la primavera de 1991 se generó un amplio consenso entre una parte significativa de las organizaciones dedicadas a la lucha contra el cáncer de mama con objeto de presionar a la administración para que modificara sus políticas de salud ${ }^{(5)}$. Bajo la premisa que los presupuestos federales discriminaban a las mujeres afectadas por cáncer y favorecían problemáticas masculinas como el VIH/SIDA o los gastos militares, la NBCC exigió un significativo incremento de los fondos destinados a la investigación y prevención de la epidemia cáncer de mama y una mayor participación de las organizaciones de afectadas en la gestión de los mismos. Sin embargo, este consenso se demostró sumamente frágil. Poco tiempo después la NBCC se desgajó en dos grandes corrientes de activismo claramente diferenciadas ideológicamente; por un lado todas aquellas organizaciones comunitarias vinculadas a núcleos feministas y lésbicos preponderantes en las áreas de Boston y San Francisco, y por otro la corriente generada en torno a la Susan G. Komen Breast Cancer Foundation (SKF), organización fundada en Dallas en 1982 por Nancy Brinker, de clara tendencia conservadora. Esta línea de fractura o ruptura ha marcado y marca aun el activismo anticáncer americano y extiende sus efectos sobre "lo dicho" en torno al cáncer de mama en buena parte del mundo occidental. Baste recordar la ubicua presencia del lazo rosa (pink ribbon), la multitud de carreras populares en lucha contra el cáncer de mama, la cantidad de productos de consumo asociados a la investigación biomédica o el gran numero de testimonios donde se narran las vivencias del superviviente para comprobar el potente impacto de los cambios culturales producidos en el ámbito oncológico durante los últimos veinte años. El análisis de estos cambios culturales, la articulación en el núcleo de la SKF de un discurso unificado y expandido sobre el cáncer de mama, junto a como este discurso es resistido, subvertido y transformado por otras formas de entender y vivir la enfermedad, constituyen el contenido de una parte significativa de los estudios culturales en el ámbito oncológico y el enfoque adoptado en el presente trabajo.

Desde esta perspectiva de cambio cultural, resulta ineludible mencionar las investigaciones realizadas por Maren Klawiter $^{(6,7)}$ en torno al movimiento activista anticáncer en la Bay Area de San Francisco durante la década de los $90^{\prime}$. A muy grandes rasgos, Klawiter describe en su labor etnográfica tres grandes corrientes de activismo que identifica como cultura de la detección precoz, cultura del empoderamiento feminista y cultura ambientalista de la prevención. Resulta de interés destacar que cada una de estas "culturas" privilegia diferentes formas de entender la enfermedad, establece distintas alianzas con los 
organismos gubernamentales, genera distintas identidades, prioriza en sus agendas objetivos diferenciados... en suma, cada activismo construye un régimen donde quedan definidas las prácticas y discursos autorizados que definen como debe ser públicamente gestionado y subjetivamente experimentado el cáncer de mama. Pero no solo el cáncer de mama no constituye un ámbito de consenso, sino que un paso más allá, la relación entre estas distintos tipos de activismo se define en términos de conflicto. Por ejemplo, en un texto de reciente aparición la socióloga Gayle A. Sulik ${ }^{(8)}$ postula que la denominada pink ribbon culture o cultura del lazo rosa generada en torno a la Susan Komen Foundation constituye un entorno que socava la salud de las mujeres con cáncer de mama, es decir, que gran parte del malestar asociado a la enfermedad viene directamente determinado por la asunción acrítica de toda una serie de postulados culturales que generan sufrimiento a la comunidad de afectas por cáncer.

Asumiendo las premisas de la actual antropología médica crítica, a partir de los trabajos de Klawiter ${ }^{(7)}$, Sulik ${ }^{(8)}$ o Stacey ${ }^{(9)}$ se constataría que lejos del consenso de la War on Cancer de Nixon o las masivas campañas de concienciación bajo la etiqueta de "piensa en rosa", podría estar desarrollándose un conflicto ideológico, político y económico no del todo incruento en torno a la experiencia de enfermar por cáncer. La complejidad de la cuestión reclamaría, por parte de los defensores de esta tesis, hacer acopio no tan solo de trabajos de campo y datos empíricos sino también de todo un aparato teóricoconceptual que permitiera analizar y dotar de sentido a las prácticas y discursos que constituyen objeto de estudio para la antropología de la salud en cáncer. A este respecto cabe señalar las aportaciones ya clásicas de filósofos como Antonio Gramsci (1891-1937) y Michael Foucault (1926-
1984) Para Gramsci ${ }^{(10,11)}$ la sociedad debe ser entendida no como un conglomerado de culturas sino como una constelación de diferentes grupos de poder; en este contexto para que una pequeña élite sea capaz de dominar a grandes masas de población la coerción o simple fuerza bruta es totalmente insuficiente $y$, en consecuencia, se hace necesario generar el consentimiento de los dominados a partir de su adscripción voluntaria a determinadas formas de interpretar la realidad que aseguren el mantenimiento del orden social. A estas interpretaciones ampliamente aceptadas como de sentido común, a estos sistemas de ideas y creencias a través de los cuales el Mundo es representado, y que establecen de hecho relaciones de dominación bajo el techo de un imaginario social compartido, es a lo que el autor italiano denomina hegemonía. Frente a ella, los grupos subalternos necesitan comprender autoconsciente y críticamente la incoherencia y la inadecuación de los postulados establecidos hegemónicamente que han absorbido de forma mecánica, para poder así elaborar un discurso contrahegemónico alternativo que les permita superar el status quo. El concepto de hegemonía de Gramsci, en suma, hace referencia a como los sectores sociales supeditados y subordinados interiorizan la visión del mundo propia de las clases dominantes en términos de consenso acrítico.

El concepto de medicalización constituye parte inherente a un porcentaje significativo de los estudios culturales realizados en el ámbito de la antropología de la salud. A muy grandes rasgos entendemos por medicalización como aquel proceso que "consiste en definir un problema en términos médicos, utilizando un lenguaje médico para conceptualizarlo, adoptando un marco médico para entenderlo y facilitando una intervención médica para tratarlo"(12). De esta forma y desde hace aproximadamente un par de siglos, se 
constata que cada vez en mayor medida multitud de circunstancias vitales que como el parto, la lactancia, la menopausia, el insomnio, el mal rendimiento escolar, los problemas de pareja, los duelos, el cansancio, el desanimo... que antes eran aceptadas como propias de la lógica natural del existir, son redefinidas ahora como problemas médicos que deben entenderse y abordarse necesariamente bajo un control "experto" ejercido por médicos y psicólogos. Este proceso de medicalización, radicalmente criticado por autores como Illich ${ }^{(13)}$, es abordado en la obra de Foucault en términos de biopoder. A grandes rasgos el filósofo francés sostiene que en un proceso iniciado mediado el siglo XVIII el tradicional ejercicio del poder sustentado en la figura de autoridad es progresivamente sustituido por una red dispersa, móvil y flexible de conocimientos y tecnologías corporales que controlan al sujeto para optimizar sus capacidades (anatomía-política) y a las comunidades para incrementar su productividad (biopolítica de las poblaciones) ${ }^{(14)}$. A través de esta red difusa construida en torno a fábricas, cárceles, manicomios, hospitales, escuelas... se implementan discursos y práctica en las que el ejercicio del poder, antes visibilizado como acto de autoridad y entendido ahora como la gestión de tiempos, cuerpos y espacios, se difumina e interioriza en un entorno que Foucault denomina "sociedades disciplinarias"(15). En este contexto el discurso biomédico, incluido el oncológico, formaría parte integrante de estos nuevos dispositivos donde el antiguo "poder" ejecutado por una instancia externa se transforma ahora en "disciplina" ejercida por uno mismo sobre uno mismo.

Asumimos así la realización de un resumen crítico de la literatura generada en torno a los aspectos culturales vinculados al enfermar y sanar de cáncer de mama bajo los siguientes supuestos teóricos:
1. Tras la apariencia de unidad se constata la existencia en nuestro entorno social de distintas maneras de entender, tratar y experimentar la vivencia de un cáncer, una experiencia imposible de reducir a una única visión o enfoque. Así, por ejemplo, entendemos que junto a la "cultura del lazo rosa" existen perspectivas alternativas distintas basadas en parámetros feministas, ambientalistas, religiosos, propios de las medicinas complementarias-alternativas, étnicos...

2. Aplicando el concepto de hegemonía descrito por Gramsci asumimos que la "cultura del lazo rosa" (CLR) generada en torno a los discursos y prácticas de la Susan G. Komen Breast Cancer Foundation ha devenido, en mayor o menor grado según zona, la forma socialmente privilegiada y potenciada de experimentar un cáncer de mama. Este discurso con pretensiones de hegemónico comporta la presencia de discursos subalternos y alternativos no homogéneos que se esfuerzan en combatir, subvertir y transformar el status quo. En tanto que la CLR no puede saturar el espacio social, no penetra de igual forma y con igual intensidad en todas las aéreas y que los sujetos responden de manera diferenciada a la experiencia de enfermar por cáncer, la posibilidad de producir marcos explicativos de esta vivencia distintos a los socialmente más autorizados se encuentra siempre presente. Así pues, el cáncer de mama es presentado como un ámbito de conflicto social.

3. Bajo el concepto de "biopoder" desarrollado por Foucault, asumimos que el discurso hegemónico CLR, lejos de consideraciones propias de la neutralidad científica y el sentido común, se encuentra imbuido de marcados componentes ideológicos. En nuestro caso, la idea de "sociedad disciplinaria" y el consenso en torno a la necesidad de 
vigilancia como elemento central de esta disciplina constituyen un referente teórico.

Ante la ausencia en nuestro país de investigación empírica en torno a los aspectos culturales asociados al cáncer de mama, los objetivos de la presente revisión se centran en recoger las principales aportaciones de la antropología médica crítica sobre los cambios socio-culturales más significativos vinculados al universo oncológico durante los últimos veinticinco años. Para ello, presentamos en forma de decálogo lo que el análisis de la literatura revela como ámbitos de problematización y conflicto, es decir, aquellas asunciones básicas sobre las que se sostiene el discurso hegemónico CLR y que son críticamente cuestionadas por discursos subalternos como el feminista o el ambientalista. Lógicamente, nuestra experiencia clínica en el Instituto Catalán de Oncología (ICO) y el contacto permanente con el complejo asistencial-institucional forma parte también del bagaje activado en la confección de este decálogo descriptivo. En todo caso, y a la espera de futuros trabajos de campo, el objetivo de este resumen crítico es generar un debate reflexivo en torno hasta qué punto la realidad cultural del cáncer de mama en nuestro país se ajusta o no a los parámetros hegemónicos en el mundo anglosajón, o hasta que punto "lo dicho" sobre el cáncer en los países de nuestro entorno puede resultarnos de utilidad para comprender un poco mejor la experiencia de ser diagnosticada y tratada de cáncer que nos relatan las pacientes.

\section{A. EL ENEMIGO PALPABLE EN ESCENARIOS REALES}

En su forma básica, entendemos que las metáforas bélicas, procesos de territorialización de lo fenomenológico, permiten a las pacientes dar sentido y lógica a una experiencia como el cáncer compleja y di- fícil de abordar; la metáfora articula la realidad, la hace comprensible. Podrían surgir de esta manera reinos enfrentados en una feroz batalla, no exenta de momentos de calma y aparente reconciliación; ejércitos irreconciliables entre los cuales, como en todas las guerras, no dejamos de encontrar también relaciones de solidaridad y concordia entre los bandos enfrentados; fronteras móviles y porosas que son constantemente violadas por tránsitos irregulares y regulados; burocracias encargadas de otorgar salvoconductos y planificar la construcción de arsenales armamentísticos; deseos de paz y deseos de sangre. De la contraposición en términos bélicos entre salud y enfermedad nacen figuras y personajes que actúan siguiendo una lógica de confrontación. Si el cáncer es socialmente descrito y entendido como una lucha, el paisaje de batalla entre dos reinos enfrentados deviene una herramienta analítica que puede ayudarnos a entender la experiencia de vivir la enfermedad. Sin duda, la guerra y la necesidad de enemigos sólidamente perfilados constituye una constante en nuestra historia como especie; desgraciadamente, una parte ineludible de nuestra existencia social.

\section{A.1. A nuestros temores ocultos: el cáncer como epidemia}

La presentación de la patología oncológica como epidemia constituye un elemento transversal en gran parte de las culturas del cáncer. Por ejemplo, en los orígenes del activismo anticáncer francés estas primeras organizaciones, nacidas en la década de los 20' del pasado siglo, necesitaron generar su propio nicho en el "mercado de la caridad" y defenderlo de competidores muy agresivos. La I Guerra Mundial (1914-1918) pobló Francia de soldados mutilados, rebrotes virulentos de enfermedades infecciosas, niños huérfanos y viudas sin recursos... un contexto 
en el que resultaba casi imposible captar recursos de la administración y las clases acomodadas para el cuidado y cura de los pacientes con cáncer ${ }^{(16)}$. En este contexto las organizaciones francesas, o las campañas masivas de educación pública en torno a la idea de do not delay en los EUA ${ }^{(17)}$, optaron por vincular el cáncer a formas de presentación epidémica con el objetivo de definir la enfermedad como un grave problema social que requería de una respuesta decidida y urgente. Así, ya en sus fases iniciales, la cruzada contra el cáncer necesitó de la presencia de un formidable enemigo para justificarse; la experiencia de un cáncer como catástrofe que afecta a un creciente sector de la población constituye una constante en nuestra relación histórica con esta enfermedad. Sin embargo, el incremento en la incidencia del cáncer de mama es un fenómeno epidemiológicamente polémico ${ }^{(18,19)}$. Sin negar el evidente aumento de casos, los distintos patrones de incremento detectados en diferentes áreas, la generalización en el uso de la terapia hormonal sustitutoria (THS), cambios en patrones reproductivos, la instauración de programas de detección precoz o la discutible inclusión en el terreno oncológico de las patologías in situ, son solo algunos de los factores que dificultan valorar el fenómeno con precisión. Pese a ello, la concepción del cáncer de mama como epidemia descontrolada no ha perdido en fuerza y consistencia, sin duda a consecuencia del incremento de casos nuevos, pero también por la acción de otros mecanismos de carácter más cualitativo que al extender el número de personas afectadas dotan de mayor gravedad al cáncer como azote epidémico:

1. Tradicionalmente el cáncer de mama se había concebido en términos de episodio tras el cual unas personas fallecían y otras se recuperaban; pasado un cierto tiempo tras la cirugía y ante la no recurrencia, se consideraba que la mujer afecta se había curado de la enfermedad y podía normalizar completamente su vida(20). Sin embargo, progresivamente se ha consolidado la concepción de la patología oncológica en términos de cronicidad ${ }^{(21)}$. Por ejemplo, desde el manifiesto del 2011 de la Federación Española de Cáncer de Mama se explicita como objetivo: "conocer mejor las dificultades derivadas de la atención a la supervivencia de larga duración de mujeres con cáncer de mama (...) los problemas laborales y sociales de las mujeres afectadas, la asistencia psico-social, la rehabilitación física, y el control de los efectos adversos, incluyendo las situaciones que suponga limitaciones de la autonomía personal."(22). Hoy en día la lógica de la rehabilitación física y psicológica gana peso respecto a la lógica de la curación ${ }^{(23)}$, configurándose así una amplía población de expacientes de cáncer con unas necesidades específicas que requieren ser atendidas ${ }^{24,25)}$.

2. Si el concepto de supervivencia en su acepción médico-estadística informa sobre la ausencia de patología entre los cinco-diez años tras haber finalizado el tratamiento, desde la National Coalition for Cancer Survivorship ${ }^{(26)}$ se redefine el término de superviviente para calificar ahora a todo sujeto con cáncer desde el momento mismo del diagnóstico hasta el final de sus días. Todo paciente con cáncer es ahora un superviviente, prescindiendo de cualquier otra consideración. Y aún más. Todas las personas del entorno del paciente como familiares, amigos, compañeros de trabajo, vecinos... todos aquellos de alguna manera afectados por la presencia de la enfermedad deben ser también considerados supervivientes según la nueva definición de la NCCS. El diagnóstico ya no es requisito imprescindible para formar parte 
de la comunidad anticáncer; el simple contacto con un paciente oncológico, o mejor, la firme intención de luchar contra la enfermedad y solidarizarse con aquellos que la padecen otorga ya carta de ciudadanía en la sociedad de los nuevos movimientos anticáncer. Se conforma así no tan solo una comunidad extendida, sino una comunidad indiferenciada donde conviven en términos de igualdad los sujetos durante diez años asintomáticos, el enfermo actualmente en quimioterapia y todos sus entornos de relación, unidos bajo una misma voluntad y objetivo. El concepto de expaciente deja de tener sentido; todos somos de alguna manera supervivientes y lo seremos durante toda nuestra vida, amalgama informe de sujetos que refuerzan sus lazos de solidaridad en tanto comparten un mismo sufrimiento potencial y el compromiso de luchar contra el cáncer.

3. El riesgo ha pasado a constituir uno de los parámetros centrales de nuestro entorno cultural $y$, en consecuencia, el eje a partir del cual articulamos en buena parte nuestras relaciones con el enfermar ${ }^{(27)}$. Una consecuencia de este fenómeno radica en que, si hasta la década de los 70’el paciente afecto y la detección precoz constituían la diana preferente de la acción terapéutica y las campañas de salud pública, en la actualidad es el riesgo a padecer cáncer el foco de gran parte de la actividad biomédica. Más allá del todavía escaso porcentaje de sujetos a los cuales es posible diagnosticar una mutación genética predisponente ${ }^{(28)}$, son los hábitos de vida poco saludables y los entornos oncogenésicos los elementos que facilitan la adscripción masiva de gran parte de la población al mundo de la oncología ya que, en menor o mayor grado, todos y cada uno de nosotros somos susceptibles de ser valorados en términos de riesgo. Aquella antigua medicina que pretendía simplemente $\mathrm{Cu}$ rar a la paciente con cáncer de mama, se propone ahora aliviar el sufrimiento de una multitud de patients before their time $^{(29)}$. Resulta ya impensable sustraerse a la fuerza gravitacional que a través del riesgo el cáncer ejerce en nuestro entorno socio-cultural.

Más allá pero de estos aspectos cuantitativos o de reclutamiento masivo la construcción del cáncer epidémico presenta unas características que lo singularizan respecto a otras patologías. La vivencia occidental de epidemia, forjada en las grandes pestes e infecciones que asolaron Europa a mediados del siglo XIV(30,31), estuvo siempre vinculada a la idea de alarma extrema ante un peligro eminente de destrucción del orden social. A través de testimonios como los de Daniel Defoe de la peste londinense de $1665^{(32)}$, comprobamos como todos aquellos pactos y leyes sobre los que se basaba la convivencia en la ciudad quedaban en suspenso ante la presencia de la plaga. La peste no era una simple enfermedad; era la encarnación de un caos y una barbarie que sobrepasaba las habilidades del médico ${ }^{(33)}$ y hacia precisas medidas destinadas a restablecer el orden alterado por la gran mortandad entre las masas de población depauperada. Ya sea en sus formas de exclusión asociadas a la lepra o bajo el precepto de encierro y control vinculado a la peste ${ }^{(34)}$, las clases dirigentes urbanas, normalmente alejadas del foco epidémico, centraban sus esfuerzos en fortalecer el orden cuestionado por el miserable moribundo. Sin embargo, el cáncer de mama presenta un patrón peculiar distinto al de la infección; la incidencia de la enfermedad es mayor entre las naciones desarrolladas y las clases medias y altas respecto a los Países del Sur y las clases menos favorecidas. Una de las lecturas tradicionales y más potentes 
del cáncer es aquella que lo vincula a los procesos de industrialización y urbanización ${ }^{(35,36)}$, es decir, el cáncer constituiría el precio a pagar por ser "civilizado", el peaje en nuestro tránsito de lo natural hacia las sociedades del bienestar; envejecimiento de la población, estrés, nuevas pautas reproductivas y de crianza, sobreexposición a estrógenos naturales y artificiales, contaminación ambiental y alimentaria, pautas vitales insalubres, consumo de tóxicos... El cáncer de mama es descrito como la epidemia de los países industrializados y en vías de desarrollo, una epidemia que nos afecta en tanto nos alejamos cada vez más de los tradicionales estilos de vida naturales. Desde esta lectura del cáncer la amenaza epidémica al orden social se ve reforzada; a diferencia de las enfermedades infecciosas como la peste, el SIDA o la tuberculosis, son justamente las clases más favorecidas las que se encuentran en mayor situación de riesgo. Pinell y Brossat ${ }^{(16)}$ apuntan que cuando los médicos militares y las damas de la aristocracia francesa que fundaron la French-Anglo-American Anti-Cancer League en 1918 reclamaban mayor atención y más recursos en la lucha contra el cáncer no tan solo apelaban a la solidaridad y espíritu altruista, sino que plantaban la cuestión como un ejercicio de autodefensa de clase; Lanz y Booth $^{(37)}$, en esta línea argumental, indican que gran parte de las campañas publicitarias de prevención en EUA se focalizan y muestran jóvenes mujeres profesionales, en un entorno de familia tradicional y elevado estatus socio-económico, quedando así las amplias capas de población hispana o afroamericana, los grupos más desfavorecidos socialmente, excluidas de la iconografía hegemónica del cáncer de mama. El cáncer de mama como una terrible "epidemia ciega" e indiferenciada, una epidemia de la que nadie está a salvo. Según corrientes feministas representadas por Lanz y Booth ${ }^{(37)}$ esta visión del cáncer esta ideológicamente bien encuadrada: a diferencia del competidor SIDA, que afecta a grupos marginados y estigmatizados como homosexuales y toxicómanos, la epidemia del cáncer es más peligrosa en tanto menos discriminativa, una epidemia que ataca incluso a las madres jóvenes, los segmentos de población mas "inocentes". Todos estamos en peligro, todos debemos luchar contra el cáncer; como indicaba una revista de la prensa rosa "El cáncer no discrimina, no entiende de clases sociales, ni de anonimatos o popularidades...(38).

Esta supuesta amenaza al orden social que representa la lectura epidémica del cáncer de mama podría tener importantes repercusiones en las políticas generadas con el objetivo de controlarla. Frecuentemente, bajo el paraguas de la epidemia se han desarrollado todo un amplio complejo de discursos y prácticas centrados en la idea de estado de excepción. Por ejemplo, el testimonio de Defoe ${ }^{(32)}$ hace hincapié en las medidas que adoptó el gobierno municipal de Londres para impedir la extensión de la peste; entre las más polémicas, clausurar las casas donde se había declarado un caso impidiendo salir de ellas a las familias, condenándolas así a una muerte segura entre grandes sufrimientos. La excepcionalidad y peligro de la plaga configura una situación en la que, recogiendo la terminología de Agamben ${ }^{(39)}$, el hombre queda reducido a nuda vida, es decir, un mero fenómeno biológico, un trozo de materia física aislada, desprovista de cualquier tipo de vínculo, ley u obligación. Es justamente esta peligrosa hiperbiologización del enfermar, en la que el cuerpo es sometido en tanto "carne", el mecanismo inherente al paroxismo epidémico que ha intentado justificar genocidios y la suspensión de todo derecho ${ }^{(40)}$. Históricamente la epidemia es terreno abonado para la prohibición, las reglamentaciones, la disolución de la intimidad, la exclusión, el etiquetaje social, el aislamiento, la reclusión 
preventiva, la discriminación... el término de epidemia, como nos demuestra nuestras recientes experiencias con el SIDA o la tuberculosis ${ }^{(41)}$, debería ser utilizado con suma prudencia. Un ejemplo paradigmático que abre un interesante debate en torno a esta problemática gira sobre al renacido concepto del "buen estigma" introducido en las campañas antitabaco ${ }^{(42,43)}$. Bajo este paradigma, aplicado por las autoridades de salud pública americanas en referencia a la tuberculosis y consumo de alcohol durante la época de la Ley Seca (19201933), se afirma que a través de procesos de estigmatización se podría mejorar la salud de amplias capas de población. En tanto el miedo al estigma desalentaría la realización de conductas insanas, se propugna que todos aquellos sujetos que se nieguen pertinazmente a abandonar sus hábitos de vida perjudiciales deberían ser catalogados como de moralmente negativos y excluidos socialmente con objeto de penalizar sus conductas y el gasto sanitario que generan. Desde este paradigma se propugnaría que un cierto nivel de temor generado por la sensación de alarma constituye el mejor incentivo para asegurar un óptimo cumplimiento de las políticas de prevención y detección precoz de cualquier enfermedad. Este "buen estigma", el fomento del rechazo social de aquellas personas que incumplen las recomendaciones sanitarias y se obstinan en sus estilos de vida oncogénicos, necesitaría del clima de máxima alarma que garantiza el cáncer como epidemia descontrolada.

En resumen, la construcción social del cáncer de mama como epidemia posee una lectura político-ideológica desde posiciones feministas-ambientalistas culturalmente subalternas: (a) Incrementa la alarma social ampliando masivamente la base de afectados mediante mecanismos asociados al nuevo concepto de supervivencia y la valoración poblacional en términos de riesgo (b) Justifica la presencia y expansión de un amplio complejo anticáncer formado por redes asistenciales, asociaciones de afectadas, industria médicofarmacéutica, administraciones públicas y recursos rehabilitadores que fomentan una visión del cáncer erróneamente reducido a un problema biológico solo solucionable desde una perspectiva estrictamente medicalizada (c) Focaliza la atención en mecanismos de detección precoz que por su naturaleza tecnológica y de altos costes excluye a amplias capas de mujeres de los Países del Sur (d) Potencialmente, al generar miedo y alarma facilita la instauración de mesuras biopolíticas centradas en la idea de control y exclusión poblacional, implementando programas en los que las comunidades de afectadas pierden autonomía y empoderamiento al quedar su papel reducido a un seguimiento acrítico de los discursos y prácticas expertas del complejo biomédico. Desde esta visión ideológica subalterna financiación, orden e impacto social son los principales beneficios derivados de la alarma construida al considerar el cáncer como una pandemia descontrolada. La peste y la tuberculosis en su momento; el SIDA, la obesidad infantil o la gripe $A$ actualmente, son buenos ejemplos de las repercusiones socio-económicas y mediáticas que asegura vincular distintas condiciones biológicas al clásico patrón epidémico propio de la patología infecciosa.

\section{A.2. El cáncer y sus representaciones: el juego de las metáforas}

La utilización de metáforas constituye, posiblemente, parte consustancial del hecho de enfermar ${ }^{(41)}$. Susan Sontag nos advierte en su obra La enfermedad como metáfora ${ }^{(44)}$ que, junto a un limitado grupo de patologías como la tuberculosis, la lepra o la peste, a lo largo de la historia el cáncer se ha visto culturalmente envestido por ideas de malignidad, depravación 
moral e insufrible padecimiento. Para las pacientes, al dolor y sufrimiento propios de la dolencia se le ha añadido un suplemento de sufrimiento tanto o más doloroso derivado del conjunto de significados socialmente adscritos a la enfermedad ${ }^{(46)}$. Así, la vivencia de un cáncer, de alguna forma, se construye como la historia de sus representaciones, los "es como si..." que ha evocado, un limitado grupo de metáforas ligadas a la idea de sufrimiento y maldad que se diversifica configurando un escenario de significaciones complejo, multiforme y contradictorio casi imposible de analizar. Por ejemplo, durante gran parte del siglo XIX el discurso biomédico se encargó de establecer una asociación entre la conducta sexual desviada y el cáncer de útero, propiciando entre las mujeres vivencias del enfermar cercanas a la depravación; las relaciones sexuales frecuentes, los contactos físicos fuera del matrimonio, toda estimulación genital no destinada a la reproducción potencialmente podían causar acumulaciones y obstrucciones sanguíneas que favorecían la aparición de la enfermedad ${ }^{(47)}$. Por el contrario, el análisis que realiza Salcedo ${ }^{(48)}$ de la correspondencia de un grupo de monjas visitandinas escrita durante los siglos XVII y XVIII indica que su vivencia del cáncer de mama, lejos de la tara moral, se vehiculizaba a través de las heridas costales de Cristo en la Cruz y distintas escenas del Calvario, confiriendo a la experiencia un marcado tono místico donde el sufrimiento callado permitía un contacto más intimo con el Salvador. Un sufrimiento que podía también justificarse como un "purgatorio en vida", la seguridad que tanto dolor debería tener una compensación más allá de la muerte $^{(49)}$. Desde la perversión a la santidad, el mundo metafórico evocado por el cáncer se inserta en unos contextos donde resulta imposible dotar de un carácter unitario a los significados atribuidos a la enfermedad.
Tras este complejo juego metafórico desarrollado en torno al cáncer acecha el riesgo, como ya nos advirtió Foucault(34) respecto a las imágenes sacras expuestas en las catedrales góticas con fines didácticos y moralizantes, que de tan cargada y saturada de significados múltiples la enfermedad deje de ser comprensible por sí misma. La vivencia del cáncer en confusión constituye una constante advertencia en la obra la Sontag ${ }^{(45)}$, una patología que, a diferencia de otras enfermedades tanto a más graves, nos habla de tantas cosas al mismo tiempo que obliga a las pacientes a una incansable búsqueda de significados en un tormentoso mar de metáforas:

1. Las metáforas se suelen aplicar a objetos o conceptos próximos para facilitar su comprensión, destacando entre sus funciones básicas la de conectar dos ámbitos de experiencia diferentes con objeto de simplificar y gestionar un todo complejo ${ }^{(44)}$. Si, por ejemplo, entendemos el cáncer como una batalla nuestras múltiples experiencias bélicas nos permiten afrontarlo como un fenómeno conocido y de alguna forma previsible pero... ¿qué ocurre cuando las metáforas desbordan en complejidad? ¿o cuando remiten ámbitos poco conocidos? DiGiacomo ${ }^{(50)}$ realiza un análisis crítico de determinadas corrientes de la antropología médica que, como las representadas por Scheper-Hughes y Lock $^{(51)}$, entienden los síntomas del enfermar no como entidades biológicas sino como metáforas que nos remiten a un entorno social caracterizado en términos de disociación y desigualdad. Para estas autoras, el sufrimiento expresado por los pacientes nos hablaría no tanto de una experiencia personal de aflicción y dolor como de su posicionamiento en unas determinadas condiciones sociales que, en sus injustas contradicciones, generan en forma de 
metáfora orgánica la expresión de un intenso malestar emocional que de otra manera no podría ser explicitado. El cáncer de mama, así, se transforma en la callada respuesta metafórica contra la injusticia y desigualdad social. Aplicando este esquema al ámbito oncológico, el pormenorizado análisis realizado desde posiciones feministas ${ }^{(52)}$ de patologías como el cáncer de mama o distintos cánceres ginecológicos remitiría en su contenido metafórico a la posición subalterna que históricamente ha ocupado lo femenino en nuestra sociedad. Así, la relación establecida entre las pacientes y sus cirujanos reproduciría fielmente la dependencia y subsidiariedad a las que las mujeres se han visto sometidas en nuestra cultura respecto a lo masculino ${ }^{(53)}$; desde las culturas subalternas y a diferencia de la hegemónica de lazo rosa las metáforas en cáncer de mama nos advierten de la necesidad de transformar un orden económico injusto o romper con los esquemas patriarcales dominantes. En su versión más radical, como advierte DiGiacomo ${ }^{(50)}$ desde su posición de paciente con linfoma, incluso la propia experiencia del enfermo individual se podría ver reducida, anulada y desautorizada por esquemas interpretativos que apuntan exclusivamente a la lucha de clases o al movimiento de liberación de la mujer en sus análisis. Cuando el síntoma deviene metáfora la apertura de sendas hacia nuevos ámbitos de significación más allá de la patología pueden transformar los fundamentos sobre los que se sustenta toda la experiencia de enfermar; nuestra relación con el equipo asistencial puede modificarse profundamente si otorgamos a nuestro oncólogo el metafórico papel de adalid de una ciencia en la cual depositamos todas nuestras esperanzas de curación o, por el contrario, de representante de un poder masculino que históricamente ha subyugado a las mujeres mediante el control, la amputación y la patologización de sus cuerpos. En todo caso queda bien establecido el riesgo apuntado por DiGiacomo ${ }^{(50)}$, que la fuerza de la metáfora puede anular la voz del paciente, que el sujeto puede quedar diluido en el significado de su enfermedad.

2. La continua reproducción de la experiencia cáncer, la imposibilidad de tener acceso a ella si no es a través del lenguaje, podría acabar por reducir la enfermedad a un simple texto, una mera imagen literaria desprovista de cualquier conexión con la realidad. Desde esta perspectiva resulta pertinente el trabajo de Barbara Clow $^{(54)}$ al indicar que si bien es innegable que las asociaciones simbólico-metafóricas vinculadas al cáncer deforman la experiencia de enfermar de los pacientes, no es menos cierto que las metáforas no son entes autónomos, un universo aparte del fenómeno que describen, sino también producto de lo real en lo vivido. De esta forma frente a la tesis central de Sontag, a saber, que los pacientes experimentan su enfermedad de una manera deformada y desnaturalizada a través del complejo metafórico que nuestra sociedad genera en torno al cáncer, Clow apunta dos alternativas: (1) El carácter agonizante, doloroso, desfigurante y costoso de la muerte por cáncer, los sufrimientos vinculados a sus tratamientos, la sensación de cuerpo asaltado y frecuentemente mutilado... todos estos elementos inscritos en el ámbito de lo real justifican sobradamente la producción de unas metáforas negativas que no distorsionan la experiencia cáncer, sino que la reproducen en su dramática y terrible realidad y (2) Las metáforas constituyen herramientas que ayudan a la dar significado a 
la experiencia, en ningún caso instrumentos de utilización obligada que saturan de sentido toda la vivencia de enfermar; de esta forma, si bien resulta innegable que en torno al cáncer tradicionalmente se ha impuesto un velo de silencio y ocultación, la revisión de revistas populares de la década de los 50' apunta al mismo tiempo que un porcentaje significativo de la población hablaba libremente de la enfermedad y posibles tratamientos con sus familiares, amigos e incluso vecinos. Así, para Clow y frente a Sontag, las metáforas oncológicas mediatizarían solo parcialmente la experiencia de enfermar de los pacientes con cáncer, de igual manera que no constituirían distorsiones negativizadas sino reflejo exacto de los intensos padecimientos que comporta su diagnóstico.

En términos empíricos, a partir de las investigaciones pioneras de Lupton ${ }^{(55)}$ ha quedado establecido que las metáforas bélicas constituyen una parte activa y consustancial a nuestra manera de entender y vivir la experiencia de una enfermedad oncológica. Y es que la representación social del cáncer ha estado desde sus orígenes estrechamente vinculada a la idea de confrontación armada. Por ejemplo, en 1936 Marjorie G. Illig, presidenta del General Federation of Women's Clubs Committee (GFWC) y con el apoyo financiero de la Metropolitan Life Insurance Company, propuso a la junta directiva de la American Society for the Control of Cancer (ASCC) la creación de una legión de nuevas voluntarias dedicadas a la lucha contra el cáncer. Bajo el sugerente nombre de Women's Field Army (WFA) decenas de miles de mujeres en EUA, vestidas con uniformes militares repletos de medallas y vistosas condecoraciones, patrullaron calles y vecindarios reclamando fondos y aconsejando a la población acudir rápidamente a su médico en caso de detectar alguno de los signos de alarma sugerentes de enfermedad. Esta cruzada nacional, una de las campañas de mayor éxito en la historia de la salud pública, fue organizada en sus objetivos y estrategias como una gran operación militar; en su funcionamiento y estructura interna, en su lenguaje y simbología, nada diferenciaba al WFA de cualquier unidad del ejército estadounidense ${ }^{(56)}$. Más recientemente, en su análisis de contenido de las revistas de mayor difusión publicadas en Canadá y EUA durante los años 1991, 1996 y 2001, Clarke y Everest ${ }^{(57)}$ indican que el cáncer es comúnmente descrito en estos medios de comunicación a través de metáforas que evocan los paisajes de una operación militar; la enfermedad como implacable enemigo, los tratamientos como bombas tecnológicas, el cuerpo como espacio de confrontación y los pacientes como heroicos combatientes que no ceden un palmo de terreno ante el embate del cáncer. En una variante interesante de este universo metafórico, informa Seale ${ }^{(58)}$ que recientemente y aplicado al ámbito de los cánceres que como el de próstata o pulmón afectan mayoritariamente a población masculina, los conceptos de triunfo, confrontación, espíritu de lucha o trabajo en equipo utilizan cada vez en mayor medida el código metafórico del deporte profesional como mecanismo de expresión en sustitución de las metáforas de guerra; así, entre los universos paralelos del deporte y la milicia se establecen conexiones potencialmente útiles para dotar de significado a la experiencia de padecer un cáncer, nuevas vecindades que complementan las antiguas asociaciones entre el cáncer y sus referentes bélicos.

¿Qué lógica cultural nos podría ayudar a explicar esta persistente presencia de las metáforas militares en el universo oncológico? La críptica obra de la psicoanalista lacaniana Julia Kristeva ${ }^{(59)}$ en torno al concepto de abjection puede proporcionar algunas pistas. El influyente ensayo etno- 
gráfico de la antropóloga británica Mary Douglas Pureza y peligro: análisis de los conceptos de contaminación y tabu(60) intenta establecer la existencia de toda una serie de rituales generados en torno a la idea de polución que implican prácticas purificativas. Este binomio limpio-sucio delimita la existencia de unas sustancias corporalmente internas que como la saliva, la sangre, el esperma, la orina o las heces deben ser expulsadas al otro lado de los límites corporales, a los márgenes de un cuerpo entendido como frontera. El concepto de abject de Kristeva hace referencia justamente a aquellos objetos que el sujeto o las sociedades, como mecanismo de control y regulación, intentan expulsar de su interior pero que son imposibles de eliminar en tanto si bien son "algo" separado del individuo simultáneamente forman parte del mismo. Esta expulsión imposible de lo ajeno-contaminado que es al mismo tiempo propio cuestiona la existencia de fronteras y limites funcionales que nos permitan diferenciar entre el sujeto y el objeto, lo normal y lo anormal, lo externo de lo interno... generando culturalmente una intensa sensación de angustia y ambigüedad. Jackie Stacey ${ }^{(9)}$, lesbiana militante diagnosticada de un teratoma, afirma que la célula cancerosa no es un invasor externo como podría serlo un virus o una bacteria patógena sino algo producido por el propio cuerpo, algo que es al mismo tiempo distinto e igual al cuerpo que le da cobijo, algo que debería ser expulsado pero permanece como parte íntima del sistema orgánico viajando de incognito. El cáncer, es suma, podría ser considerado como el prototipo del "abject", ese horror vinculado al desconocimiento de las barreras que delimitan el "yo" del "no-yo", a la incapacidad del cuerpo para expulsar al Otro ante la ausencia de diferenciación. Indica Stacey que las representaciones y metáforas demonológicas asociadas al cáncer y al lesbianismo parten de un mis- mo origen: un exceso de "mismidad", la incapacidad del cuerpo para diferenciar y expulsar lo que le es ajeno y de la mujer para rechazar el deseo de sí misma. En un artículo donde analiza las metáforas generadas por el HIV/SIDA, cáncer e infartos de miocardio entre un grupo de médicos y enfermeras, Weiss ${ }^{(61)}$ retoma argumentos similares. El cáncer es representado en términos de la imposibilidad distinguir entre el "body-self" y el "non-self"; el cuerpo como algo abierto y alterado que es fuente de polución, un cuerpo extraño, distorsionado, fragmentado que se diluye en lo Otro oncológico.

Si la angustia central de la experiencia cáncer, partiendo del concepto de abject de Kristeva, se define como porosidad de la barrera que separa el Yo del Otro... ¿qué metáforas podemos construir para gestionar y disminuir esta ansiedad de tonalidad existencial? Por un lado, desde la perspectiva hegemónica del lazo rosa, todo el esfuerzo metafórico se centra en potenciar la radical diferenciación entre el sujeto y su enfermedad, es decir, generar marcos de significado donde el paciente quede situado en un territorio simbólico totalmente ajeno al de su cáncer. Las metáforas bélicas, desde esta perspectiva, no tan solo son útiles para facilitar un afrontamiento activo y fomentar el espíritu de lucha de las pacientes sino que, simultáneamente, permiten describir al cáncer como el Enemigo, la expresión más intensa de la Otredad, de lo que es ajeno, de lo que no nos pertenece. Las metáforas bélicas, en suma, son la máxima expresión del deseo de enfrentarse al cáncer como aquello radicalmente ajeno a nosotros. Desde la perspectiva feminista-lésbica representada por Jackie Stacey ${ }^{(9)}$ esta dicotomía YoOtro se aborda, en cambio, intentando diluir las diferencias. Para Stacey luchar contra el cáncer no tiene ningún sentido en tanto "ella es su cáncer", no solo su cáncer pero también su cáncer, y por lo 
tanto ¿cómo puede una paciente combatir contra sí misma? La crítica de las metáforas militares hegemónicas realizadas desde las culturas subalternas hace hincapié en que fomentan una experiencia de enfermar alienada donde el cáncer no se integra en la vida del sujeto, sino que permanece constantemente apartado en un territorio extraño que es preciso conquistar en un combate sin final.

\section{A.3. En defensa del liberalismo económico: el cáncer como producto de consumo}

Bajo el sugerente título de Pink Ribbon Inc. Samantha King(62) aborda extensamente uno de los aspectos más polémicos generados en el conflicto ideológico subyacente al cáncer de mama. La conjunción de la llegada al gobierno británico de Margaret Thatcher en mayo de 1979 y a la presidencia de los EUA de Ronald Reagan en enero de 1981 marcó un punto de inflexión que afectó profundamente las políticas sanitarias de estos dos países. En su discurso de toma de posesión Reagan afirmó que "Government is the problem", es decir, adscribía de entrada su mandato en aquella tradicional corriente liberal americana que considera que el mejor gobierno es el gobierno mínimo, que cualquier tipo de intervención estatal en el tejido social es por definición perjudicial, que solo los individuos y la sociedad civil es capaz de gestionar adecuadamente sus recursos y necesidades. Nancy Brinker, fundadora y anima mater de la Susan Komen Foundation nunca ha ocultado su adscripción ideológica al liberalismo más conservador; participó activamente junto a su marido, propietario de una gran cadena de restaurantes, en la campaña de recaudación de fondos para la presidencia de George W. Bush, recibiendo como recompensa el cargo de embajadora de los EUA en la delegación diplomática de Bulgaria durante el periodo 2001-2003. ¿Cómo reaccionó la Sra. Brinker ante el conglomerado de feministas, liberales, lesbianas, afroamericanas, intelectuales... que a inicios de la década de los 90'reclamaba con tono airado al gobierno federal más fondos para el cáncer de mama? Lógicamente, desmarcándose del movimiento. La idea que nada se debe pedir o esperar del gobierno, que solo las mujeres afectadas y sus organizaciones serán capaces de vencer al cáncer, constituye una premisa central del movimiento del lazo rosa americano. Para ello, la Susan Komen Foundation, favorecida por la gran influencia social y excelentes contactos políticos de su líder, solo equiparables a Lifestrong del ciclista Armstrong, se constituye como organización con un doble objetivo: favorecer la concienciación social sobre el grave problema que significa el cáncer de mama a través de actos multitudinarios (Race for Cure, la primera de ellas celebrada en Dallas en 1983 y en la que participaron 800 corredoras según wikipedia) e involucrar a la mayor parte posible del tejido productivo americano en la financiación de la investigación médica sobre el cáncer (fund-raising activity).

El éxito de Nancy Brinker en su misión, qué duda cabe, solo puede ser calificado como de espectacular y rotundo. Samantha King ${ }^{(62)}$, desde un posicionamiento crítico, proporciona un par de claves para entender este fenómeno del cáncer como producto de consumo:

1. La condición y práctica de la ciudadanía, vinculada al ejercicio de los derechos y obligaciones derivados de la pertenencia a una comunidad, se asocia en los Estados Unidos cada vez en mayor medida al acto de consumir. A través del consumo de mercancías no tan solo satisfacemos una determinada necesidad individual, sino que participamos activamente en la transformación de aquellos elementos de nuestro entorno social que necesitan ser mejo- 
rados. Si anteriormente, para "cambiar el mundo" y devenir sujetos de acción colectiva, los individuos se afiliaban a un partido político, participaba en unas elecciones, asistían a una manifestación o se "echaban al monte" con un fusil, junto a ello y cada vez más importante para conseguir este objetivo altruista ahora hay que comprar una marca de mayonesa o utilizar un perfume determinado. La única manera de "vencer" al cáncer es consumir; en la nueva sociedad neoliberal la ciudadanía se reafirma a través del acto de comprar en tanto la compra se vincula a la defensa de unos valores, no es un acto ideológicamente neutro. Acudir al supermercado deviene algo parecido a traspasar las puertas de un colegio electoral. No resulta pues extraño que los principales símbolos de la cultura hegemónica del cáncer se vinculen estrechamente a la marca comercial que los promociona, como ocurre con el lazo rosa y la empresa cosmética Estee Lauder o el National Breast Cancer Awareness Month con la farmacéutica-química AstraZeneca, fabricante del tamoxifeno. Y es que el cáncer de mama constituye un poderoso reclamo comercial para las marcas; si bien son muchos los posibles ámbitos de solidaridad, no son tantos los que suscitan unanimidades tan clamorosas y extendidas como los tumores en el pecho. El gran triunfo de la cultura hegemónica del lazo rosa consiste en haber conformado un ámbito de profundo consenso, es decir, ante el objetivo de "vencer" al cáncer toda la comunidad en su conjunto está en disposición de mostrar el más firme acuerdo manifestado potencialmente por el consumo masivo de aquellas mercancías vinculadas al proyecto de derrotar la más terrible de las plagas.

2. Según Lubitow y Davis ${ }^{(63)}$ pinkwashing es un término que se utiliza para "... describir la actividad de aquellas empresas que se posicionan como líderes en la lucha para erradicar el cáncer de mama al mismo tiempo que se involucran en prácticas que contribuyen a incrementar la incidencia de la enfermedad". Derivado del concepto greenwashing, o presunta defensa de valores ecologistas por parte de compañías que contribuyen a la contaminación ambiental, las empresas pinkwashing utilizarían el deseo de mostrarse solidarios de los consumidores para generar una imagen corporativa positiva y un campo simbólico que, al fidelizar al cliente, incrementa los beneficios de la empresa. Para Lubitow y Davis ${ }^{(63)}$ en este marco se facilitaría una visión reduccionista del problema cáncer de mama donde se insiste en que, gracias a las aportaciones de las grandes corporaciones y las asociaciones de afectadas, la industria farmacéutica encontrará en poco tiempo una sustancia que "cure" la enfermedad. La investigación sobre el peso de los factores ambientales en la producción del cáncer, la necesidad de más fondos públicos para controlar el incremento de casos, la atención integral y continua de las pacientes ya diagnosticadas, las dificultades de acceso a determinados tratamientos, las políticas de prevención, el impacto de las desigualdades sociales y raciales en los índices de supervivencia, el total abandono de las mujeres con cáncer de mama en los Países del Sur... estos entre muchísimos otros temas quedarían ocultos tras la lógica del pinkwashing. El activismo subalterno en Estados Unidos adopta una posición sumamente crítica ante el advenimiento del cáncer de mama como producto de consumo. Recogiendo información de la página web de Breast Cancer Action ${ }^{(64)}$, una organización de base feminista-ambientalista fundada en 1990 en la Bay Area de San Francis- 
co, constatamos el fuerte contraste de sus planteamientos respecto a los defendidos por Susan Komen Foundation. Los objetivos explícitos de BCA se centran en: 1) Enfrentadas a las políticas de las multinacionales farmacéuticas, fomentar el uso e investigación de tratamientos más efectivos y menos tóxicos en cáncer de mama 2) Luchar contra la exposición a tóxicos cancerígenos generados por la industria y 3) Crear conciencia social respecto al papel de las injusticias político-económicas y las desigualdades raciales en la expansión del cáncer de mama. Para ello BCA asegura su independencia a través de "... la estricta política corporativa de no aceptar fondos de ninguna empresa que se beneficie comercialmente o contribuya a la expansión de la epidemia...", es decir, aquellas empresas consideradas como pinkwashing que generan ambientes tóxicos y contaminados. La campaña de mayor éxito de BCA es la denominada Think before you pink, "... un proyecto iniciado en 2002 en respuesta a la creciente preocupación sobre el excesivo número de productos y promociones de venta pink ribbon. La campaña reclama mayor transparencia a las compañías que toman parte en la financiación en cáncer de mama y anima a los consumidores a mantener una actitud crítica ante las promociones del lazo rosa". A partir de estos planteamientos... ¿cabe hablar de consenso o de conflicto en el activismo anticáncer americano?

En resumen, desde el activismo culturalmente subalterno tipo Breast Cancer Action se insiste en los posibles problemas derivados de la "ciudadanía como acto de consumo", en la desnaturalización del papel otorgado a las empresas. Si en un contexto tradicional la empresa era la simple encargada de proporcionar productos al mercado para satisfacer las necesidades de la población, ahora y cada vez más la industria se encarga de mediar entre la voluntad y recursos de la gran masa de ciudadanos-consumidores y las instituciones biomédicas "expertas". De esta forma, la financiación de proyectos de investigación y detección precoz, en contexto EUA, son ámbitos de imposible control por parte de instituciones públicas que aseguren la correcta atención de estas necesidades, un ámbito donde lo estrictamente filantrópico se confunde con una posible estrategia de marketing propiciando equívocos y disfunciones que perjudican gravemente a las pacientes con cáncer de mama.

\section{A.4. Esencialismos biológicos: la medicalización del cáncer}

Según la influyente tesis de Susan Son$\operatorname{tag}^{(45)}$ todas las metáforas estigmatizadoras aplicadas al cáncer desaparecerán en el momento en que se descubra la causa que provoca el trastorno; el cáncer constituye una "enfermedad maldita" en tanto su origen nos es todavía desconocido. Cuando el cáncer quede enmarcado en sus mecanismos anatomo-fisiológicos de producción pasará a ser culturalmente considerado como cualquier otra enfermedad, libre de su carga moral, desvinculado de polémicas caracterológicas y debates psicobiográficos... la aparición de la enfermedad ya no nos diría nada sobre nosotros mismos, dejará de hablarnos a un nivel íntimo. Lo biológico se interpondrá como la única plantilla interpretativa de la experiencia de enfermar, liberando a las pacientes de la insoportable carga metafórica asignada al cáncer. Deseo poco realista en una intelectual de la talla de Sontag, pero deseo comprensible de una mujer que pasó gran parte de su vida diagnosticada de cáncer y personalmente enfrentada a su enfermedad $^{(65)}$. Lo que resulta extraño en Sontag no es tanto la voluntad de volcar sus esperanzas de curación y redención en una ciencia médica que la aliviaba de sus lógicos temores, sino lo sorprendente de un análisis que confiere a la medicina 
los beneficios de una objetividad absoluta y al cáncer la increíble capacidad de retrotraerse hasta una simple disfunción de la mecánica celular. ¿Podemos considerar, siguiendo a la filósofa norteamericana, que nuestro actual sistema biomédico constituye un ámbito libre de influencias culturales? ¿que lo estrictamente biológico se define como lo radicalmente neutro?

Primero. Quizá nuestra experiencia y concepción del cáncer se vea condicionada por las distintas estrategias terapéuticas definidas por la ciencia biomédica, los distintos ámbitos de curabilidad asignados a la enfermedad. De hecho, cuando el Dr. Germà afirma que El cáncer se cura $^{(66)}$ no está estableciendo simplemente un hecho científicamente objetivado, sino proponiendo explícitamente una manera determinada de experimentar el cáncer a partir de su condición de curable. La cura no es un hecho médico neutro a la manera de Sontag, es más bien una propuesta experiencial cargada de significados de esperanza y positividad. Por ejemplo, el destino en la historia de Frances Burney quedó fijado un 11 de septiembre de 1811 cuando, sujetada por siete hombres y bajo el efecto de un par copas de vino, vio extirpado su seno derecho afectado por un tumor. Meses después, en una extensa carta a su hermana Esther donde calificaba la experiencia como de "...un terror más allá de cualquier posible descripción...", Frances inauguraba el subgénero de las narrativas de mutilación en cáncer de mama ${ }^{(53)}$. El sufrimiento de Frances, más allá de cualquier posible descripción, era también un sufrimiento sin demasiado sentido. Hasta finales del siglo XIX el cáncer fue una más de las muchas enfermedades situadas más allá de las fronteras curativas de la ciencia médica. En un contexto de marcado pluralismo asistencial y ante la aparición de un tumor, una mayoría de personas recurrían a remedios tradicionales y curas-milagro ofrecidas por sanadores folk, pociones y emplastos para un público desesperanzo y resignado a morir en un corto espacio de tiempo. La opción de acudir al cirujano, reservada a las clases más bienestantes, solo era considerada en situaciones de enfermedad avanzada, cuando el resto de remedios habían mostrado su ineficacia; una cirugía séptica y sin anestesia asociada a una gran mortandad, junto a las muy frecuentes apariciones de nuevos tumores poco después de la intervención, hacían del cirujano un profesional absolutamente desvalorado en el tratamiento del cáncer ${ }^{(35)}$. La controversia entre los propios doctores en torno a la posibilidad que la incisión quirúrgica pudiera facilitar los procesos de metástasis dificultaba entre la clase médica su adscripción a la cura del cáncer de mama mediante cirugía ${ }^{(67)}$. Basta recurrir a la literatura histórica sobre el tema ${ }^{(35,53,68,17)}$ para poder valorar el proceso mediante el cual este sujeto marginal y de mala fama llamado cirujano a finales del siglo XIX pasa en escasos decenios a erigirse como el foco hegemónico y casi monopolístico de la actividad terapéutica, el foco que determina y condiciona la vivencia del cáncer de millones de afectadas. Cuando a inicios del siglo XX el cáncer pasa a ser entendió como una alteración de la dinámica celular localizada en sus inicios que tiende a expandirse lentamente y de forma ordenada a los órganos adyacentes, "curable" mediante cirugía o radium ${ }^{(69)}$ si es detectado en sus primeras fases, todo el énfasis médico se focaliza en la detección precoz, generando una intensa vivencia de temor entre la mujeres a la búsqueda constante de los primeros signos de alarma ${ }^{(20)}$. Ante la organización de los primeros ensayos clínicos mediada la década de los 50’ para tratar la leucemia linfocítica aguda (LLA) mediante quimioterapia, se impone una visión medica del cáncer donde los aspectos sistémicos de la enfermedad, el posible carácter inicial de las metástasis atendien- 
do a la naturaleza histológica del tumor, requiere de la incorporación al universo oncológico del temor a las recaídas y recurrencias del enfermar ${ }^{(70)}$. En todo caso y desmintiendo a Sontag, la medicalización del cáncer de mama iniciada a finales del XIX, lejos de eliminar el proceloso mundo de símbolos, metáforas y representaciones asociados a la enfermedad, quizá haya servido para incorporar nuevos significados vinculados a lo biológico a los antiguos existentes. Sirva solo como ejemplo, se podría discutir la vigencia del componente estigmatizante asociado a los cánceres ginecológicos ${ }^{(71)}$, pero resulta poco dudoso que pese a nuestro mejor conocimiento de la etiología de los tumores de ovario todo un complejo de significados vinculados al silent killer ${ }^{(72)}$, el asesino silencioso que realiza calladamente su labor de destrucción orgánica manifestando solo su presencia sintomática cuando el daño es ya irreparable, constituye un ámbito de representaciones solo entendible desde una perspectiva biomédica. $Y$ es que pese a las buenas intenciones de Sontag, junto a estetoscopios y esfigmomanómetros el maletín del doctor también está repleto de metáforas biológicas.

Segundo. Entre las características que definen nuestro Modelo Médico Hegemónico $(\mathrm{MMH})$ Eduardo Menéndez ${ }^{(73,74)}$ destaca la relación asimétrica y subordinada entre médico y paciente. En los antiguos contextos de pluralismo asistencial anteriores al proceso de medicalización el sujeto tenía la potestad de elegir entre distintos sistemas de salud para aliviar sus dolencias; la autoatención o acudir a saberes tradicionales, representados normalmente por personas de experiencia que ejercían de sanadoras en la comunidad, era una práctica frecuentemente utilizada. Indica Paterson $^{(35)}$ que el objetivo central de las asociaciones y la administración médica norteamericana hasta la Segunda Guerra
Mundial (1939-1945) se centró básicamente en intentar desprestigiar todo el saber popular y los remedios tradicionales a los que gran parte de las mujeres acudían en caso de detectar un bulto en su seno. En resumen, que el cáncer era un asunto exclusivamente médico, que había que visitar al doctor lo antes posible ante cualquier signo de alarma. Este objetivo, en buena parte alcanzado, implicaba un cambio sustancial en la manera de entender la salud y relacionarse con los dispositivos asistenciales, un cambio que Talcott Parsons sintetizó a mediados de los 50 bajo el concepto de sick role ${ }^{(76)}$. A grandes rasgos, para el sociólogo funcionalista americano, la enfermedad se caracteriza como una desviación de la norma en la cual el sujeto se ve incapaz de asumir las obligaciones sociales propias de una sociedad productiva. Ante ello, la persona debe responsabilizarse de su cura y pedir ayuda a los doctores para recuperar su condición de salud, debiendo ser penalizado si no cumple las recomendaciones médicas y persiste en su condición de enfermo. El término sick role establece entonces una relación radicalmente asimétrica entre el experto que marca las pautas terapéuticas y un paciente totalmente pasivo que se limita a seguirlas so pena de grave sanción social. Como indica Burham ${ }^{(76)}$ es difícil determinar hasta qué punto resulta todavía de utilidad el sick role como concepto analítico, pero distintas críticas realizadas desde posiciones subalternas a la cultura hegemónica abogan por la persistencia del tipo de relación médico-paciente defendida por Parsons:

1. Jackie Stacey ${ }^{(9)}$, en el tratamiento de su teratoma, sugiere que si bien en un primer momento de pluralismo asistencial la medicina tuvo que expulsar del ámbito terapéutico a todas aquellas practicas de autoatencion y folk medicine que cuestionaban sus pretensiones hegemónicas, en la actualidad la 
medicina alopática empieza a fomentar la integración de estas prácticas subalternas en la cura de la paciente bajo la etiqueta de medicinas alternativas y complementarias (MAC) De esta forma, los grandes hospitales dedicados al tratamiento del cáncer pueden abordar la patología combinando ahora la quimioterapia con una gran variedad de técnicas basadas en la fitoterapia, meditación o el quiromasaje. Para Stacey, esta continuidad estructural que permite la estrecha colaboración entre la biomedicina y las MAC se basa en parámetros estrechamente vinculados a la idea de sick role en tanto para ambas: a) El enfoque de la problemática oncológica es, aunque no exclusiva, si predominantemente curativo, es decir, el empleo de técnicas destinadas a hacer desaparecer el tumor predomina sobre las actuaciones centradas en evitar su aparición b) El enfoque es marcadamente individualizador, es decir, los elementos culturales y sociales vinculados al enfermar juegan un papel secundario c) De alguna forma se tiende a responsabilizar el paciente, y en los casos más radicales a culpabilizarlo, de la aparición de su enfermedad y d) Importante, se mantiene intacta la rígida estructura relacional de un experto activo que tiene los conocimientos y maneja los procedimientos para facilitar la curación y un paciente que es simple receptáculo pasivo de la intervención experta. Para Stacey, entre la visita a su oncólogo y asistir a una clase de tai-chi se establece una continuidad estructural que ayuda a comprender esta práctica colaborativa.

2. DiGiacomo ${ }^{(76)}$ centra su crítica en la naturaleza esencialmente asimétrica de la relación médico-paciente. En el abordaje de su linfoma DiGiacomo intenta establecer que, junto al "conocimiento" de su doctor en torno a la en- fermedad y su tratamiento, existe otro "conocimiento" tanto o más relevante en torno a su vida y su cuerpo. Así, no se trataría tanto de la obligación del médico de informar y solicitar consentimiento sino de construir una relación de colaboración donde el doctor reconozca la presencia en el paciente de un "experto" en ámbitos distintos al científico, pero igualmente importantes para la curación. En suma, que el paciente es no es simple receptáculo de un trastorno, algo que choca frontalmente con la asignación de papeles formulada desde el sick role de Parsons.

Tercero. Así como desde las culturas subalternas religiosas se minusvalora el papel de la medicina en la cura del cáncer remitiéndola a instancias trascendentes, desde sus orígenes el movimiento feminista y ambientalista se muestra como mínimo receloso y cauto, sino explícitamente confrontativo, ante el proceso de medicalización de la enfermedad. Si desde la cultura hegemónica del lazo rosa se postula que la ciencia médica constituye la única esperanza y remedio de las pacientes con cáncer de mama y muestra una total confianza en los avances de la medicina, sin negar la conveniencia de potenciar esta vía los movimientos activistas alternativos planean que quizá la biologización de la enfermedad lleve aparejado el pago de ciertos peajes:

1. Preponderancia de la curación vs la prevención, es decir, una mayoría de medios y esfuerzos se dedican a buscar una cura contra el cáncer descuidando aspectos centrales para disminuir la incidencia de la enfermedad. Por ejemplo, el nacimiento del activismo ambientalista a inicios de la década de los $60^{\prime(77)}$ bajo el potente impacto de la obra Rachel Carson Silent Spring ${ }^{(78)}$ focalizó momentáneamente el interés de la opinión pública en el papel de los pesticidas en la generación de pa- 
tología oncológica; este interés pero no tuvo la continuidad necesaria en tanto las políticas de prevención parecen quedar supeditadas a la búsqueda de fármacos contra el cáncer. De manera un tanto ingenua, parece como si un día tuviéramos que despertarnos con la noticia que se ha encontrado una sustancia que cura el cáncer, cuando de hecho la investigación en este terreno proporciona solo pequeños avances en ámbitos muy específicos. Mientras tanto, la masiva financiación del mito de la cura total y definitiva descuida e impide el desarrollo de elementos psicosociales importantes en la prevención y el cuidado del paciente oncológico.

2. Para el activismo alternativo el enfoque individualista propio del paradigma médico oculta que la práctica de la medicina es un acto social y culturalmente determinado. De esta forma se sostiene que, bajo la apariencia de un doctor abnegado y totalmente entregado a sus pacientes, subyace la presencia de un complejo industrial generado en torno al cáncer que, desde posiciones ambientalistas-feministas, debería estar sujeto a instancias de control social y comunitario en tanto la lógica e intereses económicos no siempre coinciden con las necesidades de la mayoría de población. Este énfasis en considerar la actividad del complejo biomédico como objeto de escrutinio, por ejemplo, participando directamente en los comités que fijan las líneas de investigación, controlando fondos públicos o gestionando programas asistenciales forma parte de las culturas subalternas que se niegan a ser consideradas como simples organizaciones destinadas a la mera financiación.

3. La idea de medicalización del cáncer comporta implícito todo un sistema de valores que el activismo no hegemónico cuestiona. A grandes rasgos se de- fiende que a diferencia del activismo HIV/SIDA, donde la lucha por el acceso a medicación en los Países del Sur, políticas de antidiscriminación de grupos de población desfavorecidos, enfrentamiento directo con las grandes multinacionales farmacéuticas o construcción de una red comunitaria de atención formaban parte del eje central de sus reivindicaciones, el problema del cáncer de mama ha quedado reducido a la detección precoz y los estilos de vida saludables. En resumen, que a través de la medicalización del cáncer de mama la cultura hegemónica transforma en un problema de salud individual lo que de hecho es un problema de organización social.

4. Por último, la medicalización del cáncer de mama podría comportar el riesgo de extender y fomentar más allá de la enfermedad una visión médica del existir en que cada vez un mayor número de elementos y situaciones sean planteadas en términos de un problema patológico que debe ser solucionado por un "experto". Así, por ejemplo, al mismo tiempo que el doctor William Halsted realizaba las primeras mastectomías radicales a finales del siglo XIX, el doctor vienes Robert Gersuny utilizaba inyecciones de parafina para incrementar el pecho de sus clientes entendiendo que el seno que en forma o tamaño no se ajustaba a la norma constituía un alteración que afectaba gravemente la salud de las mujeres ${ }^{(78)}$.

\section{A.5. Cancer Parade: orgullo, fraternidad y visibilidad social}

En septiembre de 1974, pocas semanas antes de su investidura como Primera Dama, Betty Ford, esposa del presidente de EUA Gerald R. Ford, informó a la prensa que había sido sometida a una mastectomía para tratar su cáncer de mama. 
El impacto de la noticia entre el público norteamericano resulta hoy difícilmente comprensible si no lo situamos en contexto. La lógica de la mastectomía radical de Halsted, el tratamiento quirúrgico que simbólicamente ha venido a significar durante decenios el triunfo de la medicina sobre el cáncer de mama, se sustentaba sobre la idea que el exceso en la resección de tejidos se justificaba en términos de curación de la enfermedad ${ }^{(20)}$. La mujer abandonaba el quirófano transformada en una mujer sana, una mujer completamente normalizada que, si no incurría en el error de hablar de su enfermedad y recurría a elementos estéticos que como la prótesis ocultaban la ausencia de seno, podía perfectamente equipararse a cualquier otra mujer. Es en torno esta lógica de la "curación-normalización-ocultación" vinculada a la cirugía radical sobre la que se conformado buena parte del aparato estigmatizador en cáncer de mama hasta bien entrado el siglo $X X^{(53)}$; que la Primera Dama de los EUA manifestara que había tenido cáncer, que le habían extirpado un pecho y que desde la normalidad más absoluta no tenía nada que ocultar constituyó en su momento un hecho sin precedentes que ayudó a muchas mujeres a relacionarse con su enfermedad de una manera distinta.

Al interpretar globalmente lo acontecido en el universo oncológico durante los últimos veinte años como un vasto proceso de desestigmatización de la enfermedad, caben pocas dudas respecto a la centralidad de todos aquellos procesos destinados a desvelar lo que antes estaba oculto, sentirse orgulloso de lo que antes podía causar vergüenza, reivindicar lo que antes quería ser olvidado. Si la lógica de la normalización basada en la ocultación imposibilitaba cualquier sentimiento de solidaridad y apoyo entre las afectadas por cáncer de mama, la visibilidad social constituirá ahora el primer mandamiento para todas las activistas de la nueva cultura del cáncer en su afán de generar conciencia (awareness) en torno al grave problema que constituye el cáncer de mama. Esta visibilidad requerirá de dos procesos que se desarrollaran en paralelo: la reconfiguración identitaria de las afectadas en términos de superviviente, como analizaremos en el apartado ocho de este decálogo, y la generación de nuevos marcos o escenarios donde la nueva identidad pueda ser mostrada y representada.

Tradicionalmente los individuos se ha reunido voluntariamente y conformado grupos con distintos objetivos y por diferentes motivos, entre los cuales raramente encontramos el hecho de padecer una enfermedad. Las agrupaciones de enfermos han sido históricamente el resultado de procesos de exclusión social ${ }^{(34)}$; la reunión de los leprosos que vivían juntos extramuros de la ciudad, los apestados encerrados en casas apartadas para evitar el contagio, los hospitales de la época clásica donde se recluía a aquellos desahuciados cercanos al morir... a los enfermos se los ha reunido, hasta el advenimiento del hospital moderno, para facilitar su exclusión, encierro y control. En el transcurso de los siglos pero la situación ha cambiado y ahora el cuerpo biológico se constituye objeto central de gran número de movimientos sociales, especialmente en forma de experiencia corporalizada que aglutina organizativamente a sujetos que han padecido una enfermedad, el cáncer de mama entre ellas, o comparten una misma condición física. Brown $(2004)^{(80)}$ denomina a este fenómeno emergía de los embodied health movements (EHM), un activismo centrado en, y partiendo de la propia experiencia de enfermar en muchas ocasiones estigmatizada, modificar aspectos asociados a la prevención, diagnóstico y tratamiento de una determinada patología. Este autor clasifica estos EHM en un continuo que abarcaría desde aquellos movimientos denominados de advocacy, 
que colaboran con las estructuras biomédicas y socializan su problema asumiendo un déficit comunitario de concienciación y escasa financiación, hasta los movimientos llamados activist, en los cuales el grupo de sujetos experimenta su patología de forma contradictoria con los postulados médicos y tratan de generar un conocimiento alternativo de su enfermedad y una identidad colectiva explícitamente politizada.

Es en este contexto de advocacy vs activist donde se desarrolla el conflicto y las tensiones entre el activismo hegemónico de la Susan Komen Foundation y los movimientos alternativos feministas-ambientalistas. Samantha King ${ }^{(62)}$ argumenta que el fitness boom acaecido en EUA durante la década de los $80^{\prime}$ puede interpretarse como parte de la respuesta neoliberal del reaganismo a la crisis económica y a las carencias del Estado del Bienestar que padecía el país. Desde estas posiciones conservadoras se entendía que la destrucción de los valores familiares tradicionales y la falta de responsabilidad personal para asumir la solución de los propios problemas constituían la base del deterioro social, propugnando un rearme moral basado en la celebración del individualismo. En este contexto, la adscripción a todo el entramado industrial generado por el culto al cuerpo y los estilos de vida saludables se cargó de significados morales; a aquel sujeto que hacía deporte, cuidaba su alimentación y se abstenía del consumo de tóxicos se le atribuye un status simbólico centrado en el autocontrol, la disciplina y la salud que favorecían su éxito social, mientras que los individuos que optaban por alternativas más hedónicas y de autoexpresión personal fueron socialmente penalizados como causantes del deterioro material y en valores que sufría la sociedad americana. Quedaba de esta manera definida la forma favorecida de visibilidad y representación que habrían de adoptar los movimientos hegemónicos en cáncer de mama, per- fectamente ejemplarizados en la Race for Cure de la Susan Komen Fountadion o la Avon 3 Days Breast Cancer Walk de la empresa cosmética como paradigma. Siguiendo el análisis etnográfico realizado por King ${ }^{(62)}$, Klawiter ${ }^{(7)}$ y Sulik ${ }^{(8)}$ :

1. Las actividades deportivas como el correr, andar, remar, escalar, nadar o bailar constituyen el marco ideal para la manifestación hegemónica de la cultura anticáncer de mama. Esta idea del cuerpo en movimiento permite la adscripción de esta visibilidad al conjunto de valores asociados a los estilos de vida saludables; gente que cuida su alimentación, que no fuma ni bebe, que práctica ejercicio... la salud como un estado voluntariamente elegido que pasa por la responsabilización personal. Desde posiciones alternativas se insiste por contra en que la salud o la enfermedad no son solamente la consecuencia de una elección realizada por el individuo, sino efectos asociados a las condiciones sociales y ambientales en que el sujeto desarrolla su vida.

2. La visibilidad hegemónica es la visibilidad de un consenso. Multitudes uniformadas con camisetas rosas transitan las calles del centro de la ciudad manifestando su compromiso en la lucha contra el cáncer, una fraternidad que avanza unida hacia el objetivo compartido de la cura. No hay disenso posible, no hay quejas ni reivindicaciones, solamente la idea reforzada de que todos somos uno unidos en un espíritu de cruzada. Desde posiciones alternativas, los actos públicos tiene un marcado tono reivindicativo; quejas a la administración por la falta de recursos para atender a las mujeres con cáncer, críticas a las multinacionales que contaminan el aire y los alimentos, denuncia a las farmacéuticas por restringir el acceso a los ensayos clínicos ... en suma, la escenificación de un conflicto. 
3. Las Race for Cure son actos festivos, grandes multitudes celebrativas que escenifican el consenso y, por lo tanto, la emocionalidad manifestada se caracteriza por su positividad. Los abrazos constantes, los saltos de entusiasmo, las amplias sonrisas y los gestos amables conforman un clima afectivo que facilita la expresión de fraternidades y solidaridades con las mujeres que sufren un cáncer de mama. Este tono alegre y festivo, cheerfulness, contrasta con la rage propia de las reuniones de ambientalista y feministas, una rabia que nace de una situación de enfermedad vivida en términos de injusticia y que se manifiesta a través de todo una abanico emocional donde predomina una violencia contenida y provocación explicita. La estética de lo bello y cuidado de la Komen deviene reivindicación de la cicatriz y los cuerpos alternativos.

4. El tenderete de alimentos ecológicos que monta la cooperativa local en la manifestación ambientalista celebrada en la Bay Area contrasta asimismo con la multitud de multinacionales que acuden a las Run for Cure de Dallas y Houston organizadas por la Susan Komen Foundation. Fabricantes de automóviles que publicitan su última promoción "lazo rosa", empresas farmacéuticas y de seguros, alimentos energéticos, mil y un cosmético especifico para mujeres con cáncer, toda la industria de las prótesis y cirugías estéticas, cadenas de restaurantes... la visibilidad pink ribbon pibota como no en torno a la idea de awareness, pero sin olvidar nunca sus objetivos fundraising de la investigación médica.

Así como la idea de epidemia descontrolada forma parte de todo el amplio espectro activista que se ha generado en torno al cáncer de mama en los últimos años, motivo que justifica la presencia de estos movimientos sociales, la visibilidad de una enfermedad tradicionalmente considerada como estigmatizante constituye también un punto de consenso entre las distintas culturas del cáncer. Posiblemente pero, este acuerdo es más aparente que real en tanto, como indica la bibliografía antropológica, el objeto desvelado es esencialmente distinto desde la perspectiva hegemónica o el punto de vista de las culturas subalternas.

\section{A.6. "Risky selfs": riesgo y prevención en oncología.}

A inicios del nuevo siglo Olsen y Gotzsche $^{(81)}$ publicaron en Lancet un metaanálisis donde informaban de la inexistencia de evidencia científica para afirmar el impacto positivo de los programas de cribaje mamográfico en la reducción de la mortalidad en cáncer de mama. La polémica suscitada obligó a la comunidad médica a replantear las bases de una práctica terapéutica central en el mundo oncológico, concluyendo unánimemente tras ello que de estos programas de screening en el grupo poblacional de mujeres situado entre los 50-69 años se derivaban importantes beneficios terapéuticos ${ }^{(82)}$. Más allá de esta evidencia, resulta sorprendente el cuestionamiento tan tardío de acciones preventivas que, en su forma primaria de autoexploración y exploración clínica, se instauraron ya a inicios del siglo XX propiciadas por una concepción del cáncer de mama como patología localizada que se expande por los tejidos adyacentes de forma lenta y ordenada. Y es que la medicalización del cáncer ha estado desde sus inicios ligada a la idea de un riesgo que hay que prevenir. Si con anterioridad al desarrollo de la teoría celular el cáncer de mama remitía para los doctores a concepciones sistémicas de la enfermedad donde factores predisposicionales femeninos como problemas en la lactancia, menopausia o una disposición melancólica 
propia de las mujeres incapaces de gestionar su mundo emocional hacían difícil las prácticas preventivas ${ }^{(83)}$, el advenimiento de la cura quirúrgica facilitó el marco del do not delay para significar la vivencia del riesgo oncológico ${ }^{(84)}$. De forma transversal, acudir rápidamente al doctor y la adhesión a la mamografía constituye uno de los ejes centrales en el activismo anticáncer. Nuevamente, esta aparente unanimidad debe ser analizada y problematizada.

Siguiendo las tesis de Odgen ${ }^{(85)}$, desde las últimas décadas del siglo XX se constata una modificación sustancial en la percepción social del riesgo a enfermar. Si hasta los años 60' esta percepción implicaba la valoración de la interacción del individuo y su entorno, dando preeminencia a los factores externos que potencialmente podían dañar nuestra salud, progresivamente el análisis del riesgo se ha centrado en aquellas características internas que permiten al sujeto, mediante un constante ejercicio de observación y vigilancia, reducir en lo posible su exposición a las situaciones de amenaza. De esta forma, mediante estos procesos de interiorización, los peligros externos han perdido peso específico respecto a lo endógeno como elemento potencialmente dañino. Todo el conjunto de ceremonias y ritos colectivos, mayoritariamente inscritos en el ámbito de lo sacro, a través de los cuales las comunidades intentaban recuperar el equilibrio alterado por una noxa exterior manifestada en forma de plaga ${ }^{(31)}$, son ahora sustituidos por una serie de prácticas privadas que remiten solamente a nuestras carencias internas e individuales. De esta forma:

1. A sus 33 años, Sue Friedman fue diagnosticada de un cáncer de mama que posteriormente se mostró vinculado a la presencia de una mutación genética. Consciente de la singularidad de su condición de portadora, Friedman fundó en 1999 una organización denominada Facing our risk of cancer empowered ${ }^{(86)}$ para aglutinar los intereses y reivindicaciones del conjunto de población en situación de elevado riesgo de padecer un cáncer. Bajo el concepto de previviente (previvor) definiendo a "... aquellos sujetos que han sobrevivido a una predisposición a desarrollar una cáncer sin haber tenido la enfermedad. Este grupo incluye a gente con una mutación hereditaria, historia familiar o cualquier otro factor predisponente", FORCE genera una nueva identidad diferenciada, la de "... aquella porción de nuestra comunidad que tiene preocupaciones y necesidades distintas a la población general, y diferentes de aquellos diagnosticados de cáncer". La idea a destacar es que por primera vez en el mundo oncológico ya no es la enfermedad el elemento unificador de la asociación, sino una posición externa a ella definida como un elevado riesgo a padecerla. El riesgo, en este caso, es experimentado con una centralidad que propicia una definición identitaria, I am a previvor, que puede llegar a saturar el self del sujeto; en vecindad con el antiguo paciente moran ahora nuevas figuras definidas no tanto por lo que son, sino por lo que pueden llegar a ser en un futuro.

2. Indica Aronowitz ${ }^{(17)}$ que al observar la evolución de la medicalización del cáncer de mama durante el pasado siglo se advierte una inicial focalización en el escaso número de mujeres sintomáticas o que se les había detectado un tumor para, progresivamente, incluir en su actividad terapéutica a un gran número de personas vinculadas a situaciones de riesgo. Esta evolución que, como indicábamos en el apartado correspondiente al cáncer epidémico, ha propiciado un espectacular incremento de potenciales pacientes ha generado también el desplazamiento de técnicas y sustancias hasta ahora exclusivas del 
ámbito de la cura al terreno de la prevención. La utilización de las mastectomías profilácticas para la prevención del cáncer en mujeres con mutación predisponente, o los ensayos clínicos realizados con tamoxifeno en mujeres sanas de alto riesgo ${ }^{(87)}$ apuntan a la idea que el riesgo oncológico tenderá a ser tratado de manera similar a la patología oncológica, creándose así una zona difusa donde cada vez más estar en riesgo de enfermar constituye en si mismo una enfermedad.

3. Remitiendo a las tesis y terminologia de Vaz y Bruno(29), estos patients before their time o risky subjects, estos previvientes generados en el ámbito de la oncología, tienen una lectura en términos de hegemonía según Gramsci o "biopoder" disciplinario según Foucault, es decir, una lectura que remite a la internalización de una visión del mundo donde parece que nos hemos convertido en enemigos de nosotros mismos $^{(88)}$. Según Cantor ${ }^{(89)}$ el tradicional paradigma de la detección precoz y el tratamiento de los tumores en sus estadios tempranos entra en crisis mediada la década de los $60^{\prime}$ ante la constatación que, pese a la cantidad de recursos destinados a la prevención del cáncer, los índices de supervivencia y prevalencia han permanecido estables durante los últimos treinta años, quizá con la excepción del cáncer infantil. Este descontento polariza posiciones en torno a la necesidad de regular aqueIlos aspectos de la actividad industrial que generan riesgo oncológico, entendiendo que el incremento de la presencia del cáncer de mama es resultado de la contaminación ambiental, versus aquellas posturas hegemónicas reforzadas por el liberalismo reaganista de los $80^{\prime}$ que enfocan el enfermar como una cuestión de responsabilidad individual. De esta forma, como indica Bell( ${ }^{(90)}$ el exceso de peso, el consumo de tóxicos, la dieta, el ejercicio continuado, el estrés... elementos que habían tenido un espacio en las concepciones hipocráticas y populares de lo oncológico y que habían sido constantemente minusvalorados por la ciencia médica, pasan a convertirse en elementos centrales en la vivencia del cáncer de mama medicalizado. En los trabajos etnográficos de Bell se constata que, en un deseo de ganar control sobre la incertidumbre asociada al diagnóstico de un cáncer, una mayoría de mujeres se involucran con mayor a menor intensidad en el universo de los cambios de los estilos de vida, nuevo paradigma preventivo. Y ello pese a la potencial carga moralista y estigmatizante del modelo; si el riesgo se reduce a la responsabilidad individual de elegir estilos de vida saludables, a un solo paso encontramos la culpabilización del paciente por generar su propia enfermedad. Si como indica Foucault la práctica del poder se plasma en la generación de discursos, conocimientos y representaciones con pretensión de hegemonía ${ }^{(29)}$, para autoras como Susan Yadlon ${ }^{(91)}$ y buena parte de las culturas alternativas a la del lazo rosa la retorica del control del riesgo a través de los lifestyles constituye quizá el eje central de una visión del mundo donde los sujetos, entendidos ahora como un potencial riesgo para su propia existencia, deben como imperativo moral autocontrolarse, vigilarse, disciplinarse en un ejercicio constante y perpetuo a fin de evitar el peligro de contraer un cáncer. La medicina centrada en la curación se ha transformado progresivamente en un medicina centrada en la vigilancia ${ }^{(92)}$.

Cuando Klawiter ${ }^{(7)}$, como representante de una visión feminista-ecológica del cáncer de mama, denomina a la cultura hegemónica del lazo rosa early detection 
and screening activism hace mención específica a la centralidad de los programas de cribaje mamográfico como el elemento básico que define un manera de entender el cáncer. Desde culturas subalternas, sin negar los beneficios de estos programas, se insiste en su condición de respuesta parcial y limitada: a) Implica una concepción del cáncer como lesión localizada que se extiende con lentitud, es decir, la mamografía pierde gran parte de su efectividad en aquellos procesos rápidos donde el tumor muestra ya en fases iniciales tendencia a la metástasis b) Genera sensación de alarma en tanto la instauración de estos programas se vincula a incrementos de la incidencia de la patología; de hecho, las cifras reales de la prevalencia del cáncer de mama se encuentran a expensas de la implantación y efectividad de los programas de mamografía c) Se vincula con la tendencia a hipertratar con cirugía pequeñas lesiones in situ de evolución incierta que no siempre implicarían gran riesgo para la mujer que las padece d) Al focalizarse en determinados grupos de mujeres de cierta edad, se descuidan políticas de prevención de las cuales podrían beneficiarse grandes masas de población e) En su utilización indiscriminada, generan un temor en torno al cáncer que facilita que muchas mujeres eviten acudir al doctor $\mathrm{O}$ instauren prácticas de autocontrol f) Son programas tecnológicamente avanzados y económicamente caros de los que no pueden beneficiarse las mujeres de los Países del Sur y g) En términos estrictos, las mamografías detectan el tumor pero no impiden su aparición, es decir, no pueden considerarse en estrictos términos una estrategia de prevención del cáncer de mama. Para el activismo alternativo el énfasis en la búsqueda de una "cura" para el cáncer de mama, la reducción de lo preventivo a los programas de screening y la atención a los estilos de vida saludables como actos de auto-esponsabilizacion personal que olvidan los aspectos socio-culturales del enfermar, son estrategias que durante el último siglo han demostrado su ineficacia para controlar la epidemia de cáncer de mama en los países industrializados. Para este tipo de activismo subalterno hace ya años que llego el momento de abordar el cáncer reduciendo el tráfico en el centro de las ciudades, controlando el uso de conservantes artificiales en los alimentos, prohibiendo la emisión de sustancias tóxicas de las industrias, generando entornos laborales saludables, facilitando el acceso libre y gratuito a los sistemas de salud...

\section{B. LA BATALLA DEL HOMBRE CONTRA SU PROPIA NATURALEZA}

En último término, el guerrero nos habla de su fortaleza. Prescindiendo de la potencia del adversario externo, lo que verdaderamente se pone en juego en cada batalla es la capacidad del héroe para desplegar todo el conjunto de habilidades que le permitirán salir vencedor del envite. Somos así nuestro único enemigo; la derrota puede ser considerada como signo inequívoco de nuestra debilidad, de nuestros miedos, de nuestras carencias. La victoria nos justifica, redime nuestras culpas, proclama al mundo nuestras virtudes. Si bien es cierto que el cáncer puede ser leído como el Gran Adversario que nos convida al combate, la batalla contra el cáncer es siempre el relato que nos narra la confrontación del guerrero contra sí mismo.

\section{B.1. Signos de fortaleza: pensamiento positivo y crecimiento personal en cáncer}

Asolada por esa extraña epidemia Ilamada neurastenia que durante el siglo XIX afecto a las mujeres de clase media y acomodada de Occidente, durante muchos años la vida de Mary Baker Eddy quedó reducida al diagnostico de su médico fa- 
miliar: "histeria mezclada con mal carácter". Esa vida marcada por la dispepsia, las úlceras, los problemas de espalda, las neuralgias, agotamientos, insomnios, melancolías e incapacitantes dolores de cabeza, quedó pero liberada cuando en 1864 Mary Baker Eddy visito un curandero local, un relojero de Porland Ilamado Phineas P. Quimby, que ejercía su labor terapéutica bajo supuestos místico-religiosos. Bajo esta confluencia Baker Eddy-Quimby se desarrollo un movimiento religioso de largo alcance denominado "Nuevo Pensamiento", donde la iglesia de la Ciencia Cristiana fundada por Mary Baker Eddy jugó un papel central hasta inicios del siglo $X^{(93)}$. A muy grandes rasgos, desde el "Nuevo Pensamiento" se defendía la única existencia real de una dimensión Espiritual, Mental o Divina de la cual todos y cada uno de nosotros formamos parte, constituyendo el mundo material una ilusión, una creación de la Mente que puede ser manipulada y transformada a través del pensamiento. En este Espíritu Eterno repleto de Amor Infinito constituyente del Todo, la enfermedad no sería más que una entelequia negativa que puede curarse a través de determinados actos y disciplinas mentales que todos podemos poner en práctica para eliminar nuestros males, conseguir nuestros deseos y desarrollarnos espiritualmente. Lo que podía haber quedado como una opción más dentro de la amplia oferta de espiritualidades americanas, y en un proceso complejo que pasa por desvincularlo de su componente religioso dotándolo de un supuesto rigor científico y su extensión a ámbitos distintos del curativo. El nuevo pensamiento ha devenido en uno de los ejes sobre los que se articula buena parte de la cultura popular del enfermar americana, una idea de positividad ampliamente extendida que de alguna forma establece la existencia de un mundo mental-emocional que es capaz de influir, modificándolos, en los procesos biológicos ${ }^{(94)}$. Junto a ello, la conformación como ideal de un individuo "positivo" caracterizado por su autocontrol, en un constante ejercicio de autoconocimiento, completamente e individualmente responsable de sus acciones, focalizado en el "uno mismo" en su afán por realizarse y crecer como persona ${ }^{(95)}$. Esta idea de positividad, de mano de la cultura hegemónica del lazo rosa, Ilegara a saturar la vivencia oncológica de una buena parte de las pacientes con cáncer de mama ${ }^{(96)}$.

Los intentos por delimitar el papel de los pensamientos y emociones en los procesos de enfermar y sanar constituyen una constante en la medicina Occidental ${ }^{(97)}$. Si bien el "Nuevo Pensamiento" y sus actualizaciones, representadas por éxitos editoriales del calibre de El secreto $^{(98)}$, abordan el problema desde la radical supremacía de lo "espiritual" sobre lo físico, de una forma más matizada todo este universo de lo mental ha compartido espacio con lo estrictamente biológico en las distintas maneras de entender el cáncer. Anteriormente desde una perspectiva etiológica, como cuando durante el siglo XIX se vinculaba la aparición del cáncer a factores predisponentes como los desequilibrios emocionales considerados propios del género femenino ${ }^{(53)}$; más recientemente en términos de afrontamiento, los aspectos vinculados a la biografía y vida interna del sujeto son reconsiderados desde la cultura hegemónica para dibujar una nueva experiencia desestigmatizada de enfermar por cáncer:

1. Este movimiento antiestigma que define en esencia a la cultura pink ribbon se ha enfrentado a sólidos obstáculos. Uno de los principales es la existencia de una secular corriente de pensamiento, de base psicoanalítica en sus orígenes científicos, que vinculó la presencia del cáncer a determinadas características o patrones psicológicos que propiciaban la aparición de la enfermedad, es decir, 
que el cáncer era consecuencia de determinados déficits psíquicos o vivencias biográficas que conformaban una psique que predisponía al enfermar ${ }^{(45)}$. Indica DiGiacomo ${ }^{(50)}$ que el gran boom editorial que supuso la publicación del libro del Dr. Siegel Love, Medicine, and Miracles a mediados de los 80' expandió la idea que "no hay enfermedades incurables, sino pacientes que no se quieren curar". A muy grandes rasgos el Dr. Siegel defendía que un grupo de sujetos, dada su conformación psicológica, necesitan del cáncer como cauce para expresar sus conflictos intrapsíquicos de tal forma que, si estos conflictos no eran adecuadamente abordados por el terapeuta, imposibilitaban la curación de la enfermedad. Si morir de cáncer era consecuencia de la negativa del sujeto a superar sus déficits... ¿como desestigmatizar una patología asociada tradicionalmente a personas con graves carencias emocionales, unas carencia que propiciaban una vivencia del cáncer en términos de culpa y vergüenza? Gran parte de este proceso pasará por redibujar la influencia de lo psíquico como factor predisponente. Si antes se entendía este como un déficit permanente e inmutable, estructuralmente constituido a partir de traumas $y$ factores de personalidad difícilmente modificables, ahora este elemento carencial se reconceptualiza en términos de obstáculo que el paciente debe superar a través de un proceso de trabajo personal madurativo, con o sin ayuda profesional. El déficit no remite ya a factores estructurales etiogénicos, sino a posibles dificultades de adaptación modificables, maleables, transformables a partir de ese eje central denominado afrontamiento positivo. Es desde la positividad, desde el "nunca tirar la toalla", desde ese trabajo constante que consiste en monitorizar y eliminar las emociones "negativas" afrontando el cáncer como un obstáculo que hay que superar, como se incardina lo oncológico con lo positivo para construir culturalmente el concepto pivote sobre el que gira la vivencia del tumor: la fortaleza. En último término, desde la cultura hegemónica superar un cáncer ha dejado de remitir a lo deficitarioestigmatizante para trasladarnos a un nuevo escenario donde celebramos y admiramos la fortaleza y positividad interna de las supervivientes.

2. La cultura hegemónica en cáncer suscribe y proporciona a las pacientes unos marcos narrativos privilegiados para generar sus relatos sobre la experiencia cáncer. Las heroic narratives constituyen el principal de ellos ${ }^{(9)}$. A muy grandes rasgos en estas narrativas heroicas se presenta un personaje simple, sencillo y bondadoso al que los demás tienen en escasa consideración. Súbitamente pero aparece un gran peligro que amenaza a la comunidad y nuestro personaje es el único que puede vencerlo. Abandona su pueblo y en su viaje consigue superar peligrosas pruebas gracias a su talento, valentía, coraje, inteligencia, entereza... normalmente ayudado por unos pocos amigos que le demuestran un amor incondicional. Tras vencer al Gran Mal retorna a su aldea, donde sus congéneres lo reconocen como un ser excepcional, un verdadero héroe. Este viaje iniciático y la superación de los peligros pone de manifiesto el verdadero destino $y$ cualidades de aquel ser antes anodino, ahora paradigma de toda bondad y fortaleza. Quedaría de esta forma establecida una conexión mente-cuerpo que recorre transversalmente, a veces soterrada y en ocasiones explicita, gran parte de nuestras actuales concepciones del cáncer y la salud. El afrontamiento en positivo deviene popular- 
mente una condición de curabilidad que ya no remite a la enfermedad o su tratamiento, sino a condiciones vinculadas a la manera de ser de la paciente. Las personas que sobreviven al cáncer, en consecuencia, no nos hablan solo de los magníficos avances técnicos y la habilidad de los doctores, sino de unas determinadas características del self que las convierten en personas excepcionales en su fortaleza de ánimo y positividad. Es este componente el que justifica la celebración pública del sobrevivir. A través de un vasto complejo desestigmatizador la enfermedad deja de hablarnos momentáneamente de las carencias y déficits de la paciente para remitirnos a su gran fortaleza y positividad.

3. Las narrativas heroicas facilitan también la lectura de otro de los elementos centrales de la cultura hegemónica del cáncer, el denominado crecimiento postraumático (CPT) Estas narrativas heroicas frecuentemente se plantean en términos de viaje iniciático, es decir, el personaje transita a través de una serie de geografías y situaciones que lo transforman profundamente; en ocasiones cambiándolo radicalmente, en otras permitiéndole descubrir "lo que verdaderamente $\mathrm{es}^{\prime \prime}$. Por lo tanto la lucha se plantea contra el Gran Mal, efectivamente, pero también como una lucha consigo mismo para cambiar o recuperar el self del guerrero en términos de optimización y mejora. Es esta pues una cruzada a dos niveles, una lucha contra el cáncer y una lucha contra uno mismo. El resultado final de la batalla es doble; por un lado se vence a la enfermedad y por lo otro lado se vence a aquellos elementos del Yo que impedían superar el cáncer y vivir en plenitud. En términos estrictamente heroicos, el sujeto sale de la batalla y por la batalla transformado en algo distinto de lo que era, una persona mejorada tras el tránsito por la enfermedad. Es justamente a este nuevo Yo caracterizado en términos heroicos, una persona empática que sabe reconocer los valores importantes de la vida, que establece relaciones intimas y funcionales con la gente de su entorno, que sabe disfrutar de las pequeñas cosas de la vida, que conecta profundamente con las aspectos trascendentales de la existencia... el Yo socialmente celebrado en las ceremonias publicas de la cultura hegemónica del cáncer y los medios de comunicación. Es conveniente recordar que ya en los primeros modelos de CPT elaborados por Tedeschi y Calhoun $^{(99)}$ se especifica el papel preeminente de determinados rasgos del sujeto $y$ esfuerzos de afrontamiento como elementos centrales para la emergencia de crecimiento personal, es decir, el CPT no es consecuencia de haber padecido un cáncer, del hecho en si, sino de una determinada manera de relacionarse con y afrontar lo traumático En términos culturales, como indican Thornton y Pérez ${ }^{(100)}$, resulta relevante que la mayoría de estudios realizados en CPT oncológico sea en muestra de mujeres con cáncer de mama, lo que informa de una conexión que, a la par de sesgar los resultados, expresa la cercanía entre este tipo de tumor y el crecimiento personal.

En el número de noviembre 2001 de Harper's Magazine Barbara Ehrenreich ${ }^{(101)}$ publicó un extenso artículo titulado Welcome to Cancerland que en escaso tiempo se convirtió en cita de referencia para gran parte de las culturas subalternas oncológicas. A partir de su propia experiencia como mujer diagnosticada de cáncer de mama, Ehrenreich realizaba en el texto una crítica ácida y profunda del entorno cultural donde se desarrolló su vivencia de enfermar. A muy grandes rasgos afirmaba que una 
positividad impuesta y opresiva, una visión naif del sufrimiento, un ejército invasor de ositos de peluche, lacitos rosas y poesías sensibleras le habían generado un malestar intenso que se sumó al malestar generado por su cáncer. Y es que para Ehrenreich el cáncer de mama nunca constituyó una oportunidad para crecer y madurar como persona, una señal que le informaba que había de hacer cambios en su vida o su mundo emocional, ni motivo de orgullo por haber demostrado fortaleza al vencer al enemigo; su cáncer siempre fue y será un episodio negro y oscuro, esencialmente injusto, que vivió desde la rabia, el temor intenso a morir y un enojo constante que durante largos meses se instaló en su vida como un vecino indeseable. Ehrenreich se sintió profundamente extraña y desplazada en un entorno cultural donde la supervivencia en cáncer de mama era motivo de celebración en carreras populares, presentado por mujeres bellas y sonrientes que suscitaban admiración, representado por tiernos ositos de peluche y esperanzadores posters de un omnipresente color rosa. Ehrenreich, que "tiró mil veces la toalla", estaba profundamente cabreada y asustada en un universo que le exigía un gesto amable y de rotunda fortaleza. Todo el complejo cultural tejido en torno a las ideas de positividad, crecimiento personal, el cáncer como "oportunidad" para cambiar y mejorar, no tan solo le resultaba extraño, sino también moralmente opresivo en tanto:

1. Si bien desde la visión de la cultura hegemónica los tratamientos médicos juegan el papel central en la terapéutica del cáncer, se reserva un espacio de curación a elementos externos a la quimio o radioterapia. La medicación y la cirugía necesitarían de una ayuda para incrementar su efectividad, un "algo más" que la paciente aporta afrontando su cáncer desde una posición esperanzada y positiva. A partir de su supuesto potencial terapéutico, la positividad deja de ser una opción libremente elegida para convertirse en un imperativo moral; si la paciente "tira la toalla" poco podrán hace sus médicos por ella. Como indica De Raeve ${ }^{(102)}$ la positividad puede Ilegar a constituir una puerta abierta para que la paciente se culpabilice y responsabilice de la mala evolución de su cáncer de mama, para generar dudas en torno a si la paciente "ha hecho lo suficiente" para curarse de su enfermedad.

2. El dispositivo positividad, al individualizar la relación de la paciente con su enfermedad, conforma una vivencia sesgada del cáncer. Al focalizarse en las supuestas carencias o fortalezas de la paciente desatiende aspectos centrales como las condiciones sociales del enfermar, planteando una experiencia donde el sujeto se enfrente a su cáncer en términos de descontextualizacion. La presencia de un entorno relacional, por ejemplo, que vive el cáncer con y modula la vivencia del cáncer de la paciente es un elemento de segundo orden cuando se enfoca el afrontamiento como una pauta de respuesta propia de cada individuo.

3. Si bien la emocionalidad "negativa" se encuentra integrada en la cultura hegemónica del cáncer de mama, no por ello deja de despertar cierta sospecha y ambivalencia. Comprensible en determinados momentos de la trayectoria del enfermo, como cercana al diagnóstico o ante los afectos adversos de la medicación, si la negatividad no se autolimita y se prolonga en el tiempo pasa a constituir motivo de preocupación ante la posibilidad que la paciente no esté afrontando su cáncer de una manera positiva. En su artículo de Harper's Magazine Ehrenreich ${ }^{(92)}$ indica que ante las amables recriminaciones recibidas por personas de su entorno 
por sus expresiones de tristeza y enojo, su única opción fue el aislamiento o manifestar un buen ánimo ficticio.

4. Si desde la cultura hegemónica el cáncer de mama es representada como una enfermedad terrible, la consecuencia lógica es que la persona que lo supera sea catalogada de una mujer excepcionalmente fuerte y positiva. Esta condición de excepcionalidad pero puede ser experimentada por las pacientes como un elemento segregador que las separa de las gentes del entorno, convirtiéndolas en "algo extraño" distinto de lo común; el haber recibido la medicación adecuada, la atención de un buen equipo terapéutico y el constante apoyo de su familia y amigos podrían ser elementos centrales en la curación del tumor que poco tienen que ver con el afrontamiento positivo y que resitúan a la mujer en una condición de normalidad reivindicada por las culturas subalternas.

\section{B.2. Identidades oncológicas: el concepto de supervivencia}

Si bien el concepto de supervivencia, en su acepción epidemiológica, es un término tradicionalmente utilizado en el universo oncológico para designar aquella proporción de casos de una población que sobreviven al cáncer en un período de tiempo determinado, actualmente este concepto se asocia a múltiples significados. Entre ellos, aquellos referentes a cuestiones identitarias, es decir, a la presentación social que de su self hacen las personas que han superado un cáncer, a cuestiones centradas en lo que uno es y cómo quiere que los demás lo consideren. Esta versión identitaria del término superviviente fue formulada por primera vez en un artículo del New England Journal of Medicine publicado en 1985 por el Dr. Fitzhugh Mullan ${ }^{(103)}$. A muy grandes ras- gos, la idea central del texto es que, a partir de su propia experiencia de paciente oncológico y pese a los resultados de las analíticas y la opinión de todos sus doctores, Mullan no se sentía curado del cáncer diagnosticado años atrás. De forma clara y directa indicaba que el paradigma dicotómico curado vs. no curado no podía capturar con exactitud las complejidades y ambivalencias de la experiencia postdiagnóstico de los pacientes oncológicos. Frente al dato objetivo que le ofrecía su doctor como signo inequívoco de haber superado la enfermedad, el paciente contraponía su vivencia subjetiva y reclama que esta fuera tenida en cuenta a la hora de catalogarlo como un superviviente que habita en "... una zona sombría del existir que no es ni estar muerto ni estar curado". Esta murky zone, un área sombría, turbia, nebulosa, definida por su indefinición entre la vida y la muerte; esta geografía de la frontera o espacio del límite es el que habita y da forma al superviviente de cáncer en la formulación original de Fitzhugh Mullan, un concepto angustiante que refleja la angustia del paciente ante el recién adquirido conocimiento de su mortalidad y la incertidumbre de su existencia.

Esta particular y trágica visión de la supervivencia oncológica, que en la actualidad permanece soterrada en el desván de algunas de las culturas subalternas en cáncer, ha gozado de sus espacios y momentos de desarrollo. El mismo Mullan, en 1986, cofundó la National Coalition for Cancer Survivorship (NCCS), una organización que pretendía aglutinar los esfuerzos de aquellas personas que habían padecido un cáncer y se encontraban, finalizada la fase aguda de su enfermedad, desatendidas por el sistema sanitario. En su obra de análisis narrativo The Wounded Storyteller ${ }^{(104)}$ Arthur Frank, retomando la perspectiva de Mullan, describe la "sociedad de la remisión" como "aquella gente que como yo, estando completamente sanos no pueden 
ser considerados como totalmente curados". Esta "sociedad de la remisión" constituiría un territorio simbólico entre la salud y la enfermedad en que el retorno a la completa normalidad después de la cura ya no es posible, una sociedad secreta e invisible en el mundo de los sanos en que sus componentes pueden ser expulsados tras recibir los resultados negativos de una analítica o una mamografía. Más recientemente, en un artículo del New York Times Susan Gubar $^{(105)}$, paciente afecta de un cáncer de ovario, afirmaba que "Ni yo ni ninguna de mis compañeras del grupo de soporte somos supervivientes... quizá deberíamos buscar una nueva palabra para esa zona intermedia y turbia en la que muchas de nosotras vivimos el día a día". Es posible que parte del problema generado por este tipo de definición del superviviente radique en las implicaciones estigmatizantes generadas en torno a la idea de lo que Zygmunt Bauman" ${ }^{(106)}$ denomina "... la lucha contra la 'baba', contra el enemigo arquetípico de la claridad y de la inviolabilidad de los limites y las identidades." En una tesis que evoca a la idea de abject de Kristeva ${ }^{(59)}$ ya comenta$\mathrm{da}$, para Bauman todas aquellas posiciones vitales indiferenciadas, informes, sin límites bien definidos y fronteras bien marcadas, generan unas sensaciones de desconfianza y temor que propician los fenómenos de estigmatización social. La propuesta identitaria formulada por Mullan, su insistencia en una murky zone turbia y nebulosa, difícilmente podía ser bien recibida por un movimiento activista del lazo rosa que hace de la desestigmatización del cáncer de mama la razón última de su existencia. La alternativa pasaría en todo caso por su contrario, la formulación de un identidad de superviviente claramente definida en términos positivos; de hecho, gran parte de lo acontecido en el universo cultural oncológico durante los últimos veinte años podría responder a la consecución de este objetivo.
Sin embargo, y pese al esfuerzo realizado en este afán desestigmatizador por parte de la cultura hegemónica, la situación actual no deja de resultar paradójica atendiendo a las siguientes circunstancias:

1. Una revisión de la todavía escasa bibliografía en torno a las cancer-related identities permite afirmar que, en los estudios realizados en el ámbito cultural anglosajón, las muestras de pacientes con cáncer se adscriben mayoritariamente al término de superviviente. Así, por ejemplo, en las investigaciones de Deimling et al.(107), Deimling et al. ${ }^{(108)}$ y Park et al. ${ }^{(109)}$, solicitando a los pacientes que escogieran la figura identitaria que los define, resulta imposible determinar que entienden los sujetos valorados por identidad de superviviente. Las dudas se ven reforzadas al comprobar que en la metodología seguida en los estudios se solicita la adscripción a la muestra sin antes haber definido con claridad las características que definen cada una de las identidades propuestas, por lo que si bien estamos en condiciones de afirmar la preferencia por el término superviviente en el entorno cultural norteamericano, no estamos en disposición de valorar con exactitud que es aquello que define al survivor y lo diferencia del resto. En términos totalmente especulativos indicaríamos que la mejor aproximación a esta cuestión es todavía una aproximación "en negativo", es decir, un superviviente en cáncer es lo contrario que una víctima en cáncer. Si caracterizamos a víctima como pasiva, con baja sensación de control, desesperanzada, hipervigilante, vulnerable, con sensación de daño e injusticia, con dificultades para responsabilizarse autónomamente de su cuidado, donde predomina una emocionalidad negativizada... po- 
dríamos esperar que el superviviente manifestara condiciones contrapuestas a las apuntadas. Estas condiciones de supervivencia identitaria, en el actual marco definido por la cultura hegemónica del lazo rosa y a falta de estudios que lo corroboren, podrían pasar hipotéticamente por: a) Todo un conjunto de procesos valorativos donde el self asociado al cáncer ocupe un espacio central en el complejo identitario del sujeto y donde la experiencia de enfermar, sin negar su componente de dolor y sufrimiento, sea también evaluada recogiendo sus aspectos positivos b) Bajo el paradigma de estilos de vida saludables y estrategias de gestión emocional, marcada sensación de control sobre los efectos y posibles recurrencias del enfermar c) Mejoría en el ámbito de las relaciones personales y funcionamiento social y d) Autovaloración positiva que podría pasar desde una mayor sensación de fortaleza y capacidad de afrontar la adversidad hasta un crecimiento postraumático explicito y completo.

Junto a la mayoritaria adscripción de las pacientes anglosajonas a una supervivencia identitaria que resulta por el momento difícil de definir con claridad, otros elementos aportan su dosis de confusión al tema:

1. El primero de ellos es que, presentando distintos modelos de enrfernar y sanar, no todas las pacientes con cáncer de mama se consideran supervivientes ${ }^{(110)}$. El estudio cualitativo de Kaiser ${ }^{(111)}$ nos proporciona información sobre los motivos por los cuales una minoría significativa de mujeres prefieren no ser identificadas por el término survivor. A muy grandes rasgos: a) La posibilidad de una recurrencia, la incertidumbre respecto al retorno de una enfermedad que esta potencialmente siempre presente, es incompatible con la idea de supervi- vencia en cáncer b) Para algunas mujeres su experiencia del cáncer de mama no ha comportado un riesgo vital, no se han sentido cercanas a su muerte y por lo tanto consideran que no han sobrevivido a la enfermedad c) En tanto el cáncer es todavía una patología connotada en términos estigmatizantes hay personas que optan por evitar la mínima referencia a su diagnóstico y d) Para algunas pacientes el concepto de supervivencia tiene un efecto reductor, es decir, toda su compleja y rica vida queda fatal e inadecuadamente resumida a la vivencia de un cáncer, obviando aspectos de su biografía tanto o muchísimo más importantes a la hora de configurar su identidad. Como podemos comprobar, si bien el concepto de survivor está cada vez más extendido, su utilización está lejos todavía de ser unánime y uniforme.

2. Siguiendo la argumentación de Kaiser ${ }^{(111)}$ parece ser que en el entorno norteamericano el concepto de survivor se encuentra muy sesgado culturalmente, es decir, su uso identifica a aquellas mujeres con cáncer de mama que se adscriben a la cultura del lazo rosa, mientras que aquellas que desde otras posiciones critican las concepciones de la Susan G. Komen Foundation rechazan esta cancer-related identity. En tanto el concepto esta en el eje del conflicto cultural, su uso implica el reconocimiento de cierta militancia pink ribbon (por ejemplo, participación en carreras populares, compra de productos, crecimiento postraumático, defensa de la familia tradicional...) totalmente alejada de las posiciones culturales subalternas en EUA. La supervivencia, como comunidad narrante, exige de un posicionamiento ideológico que expulsa de ella a las mujeres comprometidas con otras concepciones del mundo y la enfermedad. 
3. El panorama se hace más complejo a medida que introducimos nuevas variables en la ecuación identitaria del superviviente en cáncer. En su análisis etnográfico de los dispositivos asistenciales daneses Hansen y ThornhojThomsen ${ }^{(23)}$ describe la reciente introducción de una nueva lógica rehabilitadora en la atención de las pacientes con cáncer, es decir, desde lo biomédico también se generan sus propias propuestas identitarias. Si la actividad del sistema biomédico una vez finalizado con éxito el tratamiento de la enfermedad había quedado tradicionalmente circunscrita a la realización de pruebas en prevención de posibles recurrencias, se constata ahora el nacimiento de toda una serie de programas y destinados a la rehabilitación biopsicosocial de la paciente. La recuperación funcional de la extremidad superior y los controles ginecológicos, pero también las posibles dificultades psicológicas de adaptación a su condición de superviviente o los problemas de integración laboral pasan a constituir objeto de cuidado experto. Siguiendo la lógica cultural de estos autores daneses se plantean dos graves dificultades con connotaciones identitarias para este tipo de programas rehabilitadores de expansión medicalizadora. Primero, el concepto de superviviente, desde su captación por la cultura del lazo rosa, responde a la necesidad de positivizar socialmente a las mujeres que han superado un cáncer, objetivo aparentemente incompatible con potenciar la idea de la necesidad de una rehabilitación que focaliza su atención en el déficit, las carencias o dificultades del sujeto. En segundo lugar, ya los trabajos sobre narrativa oncológica de Frank ${ }^{(104)}$ apuntan a que un porcentaje importante de pacientes optan por explicar su enfermedad en términos de restitución, es decir, una preferencia por considerar que el cáncer fue como un paréntesis en sus vidas, que están perfectamente recuperadas y son las mismas personas que antes de enfermar. De ahí algunas de las consideraciones de Hansen y Tjornhoj-Thomsen ${ }^{(23)}$ en torno a las quejas de pacientes que entienden que las intervenciones post-alta médica les dificultan recuperar la tan perdida y anhelada normalidad anterior al diagnóstico.

Transitar de la posición de víctima a la de superviviente constituye el objetivo explícito de buena parte de las prácticas y los discursos de la cultura hegemónica pink ribbon. Es esta una cuestión planteada en términos identitarios. El brutal impacto que a principios de los $80^{\prime}$ supuso la aparición del SIDA, un impacto que activó pánicos asociados a una peste negra que en el siglo XIV ayudó a desintegrar el orden social medieval, activó también la necesidad de encauzar unos temores que podían afectar directamente a aquellos diagnosticados por patologías como el cáncer tradicionalmente estigmatizadas. Mientras las víctimas de la infección se organizaban en paralelo a las mujeres con cáncer de mama en las calles de San Francisco, en la lejana Texas la Susan G. Komen Foundation argumentaba que la estigmatización no tenía ningún sentido en tanto ellas no eran víctimas de la enfermedad, sino supervivientes de un cáncer ahora entendido como una oportunidad para demostrar su fortaleza y madurar personalmente. Este cambio de paradigma identitario, de gran éxito y con pretensiones hegemónicas, se enfrenta pero a la crítica de culturas subalternas donde el rol de víctima es reivindicado con dos matizaciones importantes. Primera, ser víctima no se considera motivo de rechazo y discriminación, sino una posición desde la que se reclama justicia y solidaridad. Segundo, ser víctima de la enfermedad es también serlo del complejo industrial que contamina nuestro aire 
y alimentos y de una sociedad patriarcal que relega a la mujer a la condición de mero objeto.

\section{B.3. Cáncer y estética: en torno a la idea de feminidad}

En nuestro imaginario medieval las oscuras y sucias calles cercanas a la catedral, las escaleras de la iglesia y las puertas del convento, están pobladas de mendigos harapientos que muestran muñones infectados, llagas purulentas, miembros seccionados. Esta exhibición impúdica de lo deforme obedecía a una lógica de la caridad, hoy olvidada en Occidente, que vinculaba con estrechos lazos a aquel que ofrecía la limosna con el menesteroso que la recibía ${ }^{(112)}$. A muy grandes rasgos y en términos simbólicos, el pobre enfermo que mostraba sus pústulas se identificaba con la figura del Jesús Sufriente, una reencarnación del Crucificado que proporcionaba al poderoso la oportunidad de salvar su alma a través del acto caritativo. En este intercambio sacro el máximo beneficiario era aquel que, con una simple moneda de cobre, reconocía y aliviaba en el pobre el sufrimiento de su Salvador; la cicatriz era por todos entendida como la marca identificativa de aquel que proclamaba al mundo "Yo soy el Cristo", se imbuida de unos significados religiosos que no llamaban a la lástima ni la empatía sino a una justicia reciproca en la cual para recibir la Paz y la Gracia había previamente que desprenderse de lo material socorriendo a un Jesús necesitado. $Y$ es que la cicatriz como marca siempre ha actuado como un potente generador de significados y moralidades. Más recientemente, en la introducción de su estudio etnográfico, Maren Klawite ${ }^{(8)}$ se confiesa impresionada ante la presencia de RavenLight, una mujer que acudía a las marchas homosexuales vestida solo con unas medias negras y una ceñida minifalda de cuero mostrando su torso con un único pecho. Para Klawiter, lejos ya del simbolismo religioso de las sociedades secularizadas, RavenLight representaba la posibilidad de una nueva relación corporal tras ser mastectomizada, una nueva forma de vivir el cuerpo desprovisto de ocultaciones e imbuido de ese recién descubierto orgullo que caracterizaba a la comunidad gay de la Bay Area de San Francisco a principios de los 90'.

Y es que la historia del pecho, así como la historia de su patología, tiene también una lectura estética en la que la imagen personal y sus representaciones sociales se superponen a distintas maneras de vivir la enfermedad y transmitir sus significa$\operatorname{dos}^{(113)}$ :

1. En 1952 Terese Lasser fue una de las muchas mujeres a la que extirparon su pecho en el Memorial Hospital de Nueva York como tratamiento de un cáncer de mama ${ }^{(114)}$. Inició en este periodo su labor visitando y ofreciendo apoyo y consejo a pacientes recién mastectomizadas hasta llegar a generar la mayor y más potente organización de voluntariado en cáncer, Reach to Recovery International (RRI) Debido a las reticencias del estamento médico, RRI no fue adoptado como programa de la American Cancer Society (ACS) hasta 1969, momento a partir del cual paso a ser frecuente que multitud de pacientes afectas por cáncer de mama recibieran la visita de voluntarias, seleccionadas en función de su buena imagen y animo positivo, con el objetivo explicito que sus vidas volvieran a ser igual que antes de la enfermedad. Para ello, y junto a tablas de ejercicios de rehabilitación y consejos en hábitos de vida, RRI proporcionaba información sobre prótesis, lencería y cosmética a fin que la afecta pudiera mostrar una apariencia atractiva y femenina a pesar de la extirpación de su seno. Entre ellas Audre Lorde, una poeta negra vinculada al 
movimiento feminista-lésbico que con su obra The cancer journals ${ }^{(115)}$ se ha convertido en uno de los referentes de las culturas alternativas en cáncer de mama. Lorde defiende en su texto una noción de feminidad completamente distinta a la de RRI. Para ella la ausencia de su pecho no era algo a ocultar mediante prótesis, sino un elemento que al hablar de su vida y experiencia formaba parte de su identidad, un elemento que debía ser integrado en una biografía marcada por la sensación de exclusión. Como mujer, como afroamericana, como poeta, como lesbiana, su cicatriz debería hablar libremente de ella y de su posición marginal; la feminidad no tenia para Lorde nada que ver con tener uno o dos pechos, con el atractivo sexual, con mostrar una buena imagen y una figura estilizada, sino con asumir y luchar contra su condición de outsider. Para Audre Lorde esconder la cicatriz de su torso era algo tan absurdo como intentar ocultar el color de su piel.

2. $Y$ es que en un movimiento amplio $y$ profundo que ha acabado por incluir también al cáncer de la mama, se han establecido profundas conexiones entre la estética y la salud que influyen en nuestra experiencia de lo oncológico. Bajo el supuesto que el cáncer de mama y sus tratamientos repercuten negativamente en la imagen de la mujer generando sufrimiento emocional y pérdida en el sentido de feminidad, en gran parte de nuestros hospitales se desarrollan talleres de cosmética destinados al aprendizaje de técnicas de maquillaje. Desde las culturas alternativas este nuevo fenómeno, propiciado desde perspectivas del lazo rosa, resulta injustificable en tanto reproduce una visión tradicional de la feminidad donde los aspectos estéticos vinculados a la buena imagen y resultar sexualmente atractiva parecen devenir condiciones necesarias para el bienestar de las mujeres. Mientras parece que los hombres no son receptivos a los beneficios del abordaje estético-terapéutico, desde la prensa rosa se insiste constantemente en lo guapísima que esta y lo bien que luce determinada actriz tras su cirugía de mama, incidiendo en toda una serie de tópicos sobre la belleza y la feminidad rechazados desde las culturas del feminismo. Esta exaltación de lo glamuroso asociado al cáncer de mama tiene en la actualidad su máxima expresión en el exitoso movimiento denominado con el sugerente nombre de Crazy Sexy Cancer. Tras su paso por el programa de Ophra Winfrey, adalid del pensamiento positivo en EUA, Kriss Carr se ha convertido en un referente para la comunidad pink ribbon americana. Conjugando los tratamientos biomédicos con dietas vegetarianas, masajes y espiritualidad zen, Carr transmite en su obra y su comunidad virtual un optimismo y positividad radical, entendiendo el cáncer como una gran oportunidad que le ha permitido madurar, fortalecerse y crecer como persona ${ }^{(116)}$. Todo ello vinculando la enfermedad a un entorno donde predomina una atmósfera sexy y sensual de sonrisas sugerentes. Y es que la cultura hegemónica es también una propuesta estética.

3. De igual forma, toda propuesta estética conforma una referencia moral. Comentábamos en el quinto apartada de este decálogo que en el contexto del fitness boom generado a inicios de la década de los $80^{\prime}$, la adscripción a estilos de vida saludables y prácticas de cuidado corporal se asociaba a un universo simbólico donde el autocontrol, la disciplina y la autoresponsabilización en el mantenimiento y mejora de la propia salud constituirían características definitorias del buen ciudadano 
neoliberal. La manifestación plástica de esta adscripción al "cuidarse" conforma una estética que, lejos de la simple belleza, se configura a partir de la imagen saludable. De esta forma, cualquier signo externo que señale la presencia de una enfermedad o dificultades en controlar una conducta se aparta del canon estético socialmente promocionado; por supuesto que la gente enferma de cáncer, pero ello no es óbice, todo lo contrario, para que no procure mostrarse ante los demás como una persona saludable. En un movimiento que abarca múltiples manifestaciones, como por ejemplo el sobrepeso o el tabaquismo, para las culturas subalternas la antigua normalización que consistía en intentar disimular en lo posible la ausencia de un pecho a fin de poder ser considerada una mujer como todas las demás, se ha transformado hoy en día no tanto en la ocultación sino en mostrar una imagen que reafirme nuestro compromiso con cuidar de nuestra salud. Intentar estar bella es tanto como manifestar el compromiso de estar sana.

Lantz y Booth ${ }^{(37)}$, desde una perspectiva feminista, plantean la cuestión de la feminidad en cáncer de mama inscribiéndola en los profundos cambios que partir de la II Guerra Mundial han modificado los roles genéricos en las sociedades occidentales. La tensión generada por estas transformaciones propiciaría que desde ciertos sectores se defendieran valores tradicionales que, atendiendo a parámetros biológicos, aseguraran el mantenimiento de un status quo definido por la desigualdad y discriminación de la mujer. En su análisis de la prensa americana durante el periodo 1980-1995, estas autoras constatan que buena parte de los avances logrados desde la década de los $60^{\prime}$ por los movimientos feministas en el control reproductivo son presentados ahora como potenciales riesgos oncológicos. De esta forma, el uso de contraceptivos orales, la nuliparidad o reducir el número de hijos, la opción por la lactancia artificial o retrasar el primer parto constituirían prácticas de riesgo cada vez más generalizadas que explicarían el notable incremento de la incidencia del cáncer de mama entre las mujeres americanas y europeas. La tesis de estas culturas subalternas de base feminista se manifiesta así con claridad explicita. En el marco del auge de las políticas neoliberales y antiestatilista de los 80', un movimiento profundamente conservador e individualista, el cáncer de mama es utilizado a través de organizaciones pink ribbon como la Susan G. Komen Foundation para la promoción de valores adscritos a una feminidad tradicional. La necesidad de estar guapas y cuidar de la propia imagen, de resultar sexualmente atractivas a pesar de los efectos de la enfermedad y sus tratamientos, constituiría desde esta perspectiva subalterna un intento de desestigmatizar el cáncer profundamente ideologizado, un intento por retomar el camino de unos roles genéricos donde la mujer quedaría relegada a sus tradicionales funciones reproductivas y cuidadoras.

\section{B.4. Psicología y cáncer: personalidad, trauma y taichí}

Según la tesis central de Susan Sontag ${ }^{(45)}$, el cáncer quedará completamente libre de sus significados y representaciones negativas cuando conozcamos las causas de la enfermedad, es decir, perderá su potencial estigmatizante cuando se vea reducido a una cuestión estrictamente médica, de simple dinámica celular. Indicábamos en el segundo apartado del decálogo las dificultades asociadas a este proceso de reduccionismo biológico. Resulta difícil pensar que nuestra relación milenaria con el cáncer pueda vaciarse de significados culturales, sobre todo teniendo en cuen- 
ta que el ámbito biomédico constituye un potente generador de metáforas. Además, por la puerta lateral de la medicina científica desarrollada durante el siglo XIX han entrado en escena nuevas compañías que, como la psico-oncología, realizan también su particular contribución al cesto cultural de lo oncológico.

Imposible en pocas páginas analizar las muchas y notables aportaciones realizadas desde la psicología a nuestra comprensión de la experiencia de vivir un cáncer. En todo caso entendemos que, siguiendo tesis propuestas por Foucault ${ }^{(117)}$, el punto central de la cuestión desde una perspectiva cultural podría radicar en que el tratamiento psicoterapéutico permite trasladar el punto de aplicación curativa desde la lesión orgánica a un nuevo territorio caracterizado como deficitario o deteriorado distinto de lo estrictamente biológico; se legitimaría así como conocimiento científico un territorio psi diferenciado de la enfermedad que permite la generación de toda una serie de discursos y la aplicación de toda una serie de prácticas destinas a la transformación de los individuos. De alguna forma, lo psico-oncológico abre las puertas a la intervención y amplia el foco más allá de la topografía estrictamente orgánica dibujada por la biomedicina, introduce elementos que bajo la etiqueta de lo psíquico se definen como distintos de lo celular. La psicología ubica al sujeto en el universo de lo oncológico desde distintas perspectivas:

1. En 1981 Morris y et al. ${ }^{(18)}$ introducen por primera vez el concepto de patrón de personalidad tipo C, un conjunto de rasgos centrados en la defensividad, los déficits de expresión emocional, la racionalización, la necesidad de armonía y la represión que presuntamente predisponen a la aparición de un cáncer. $Y$ es que el vínculo entre una emocionalidad desarreglada, en términos de represión o de descontrol y la apari- ción de la enfermedad constituye una constante en la historia del cáncer de mama $^{(119)}$. Durante todo el siglo XIX se consolida todo un conjunto de condiciones que, bajo la supuesta debilidad e hiperexcitabilidad del sistema nervioso de las féminas, facilitan la aparición de la patología. Así, por ejemplo, todo el universo de la tuberculosis se puebla de mujeres de una gran sensibilidad, espirituales, inteligentes, muy reactivas emocionalmente, un patrón que facilita la instauración de la tisis ${ }^{(120)}$. Lo constitucional, a través de lo emocional, se construye como vía de acceso de lo psicológico a los cánceres femeninos.

2. En un derivada lógica, la emocionalidad pierde gran parte de la connotación constitucional que remite a las maneras de ser para devenir un elemento funcional, es decir, vinculado a la inadecuada gestión de las emociones. La necesidad de identificarlas, prestarles la atención adecuada, poder regularlas y sustituirlas por otras más adaptativas, elementos centrales de la denominada inteligencia emocional, forman parte del bagaje psicológico asociado al cáncer. Y ante todo, la paradigmática necesidad de expresar(121); los beneficios derivados de la ventilación de los sentimientos, emociones negativas, experiencias adversas, episodios traumáticos, todo ese conjunto de elementos que de alguna forman configuran una psique disfuncional, constituyen buena parte de nuestro conocimiento y práctica psico-oncológica.

3. La aparición en 1988 del cuestionario Measurement Adjusment of Cancer $(\mathrm{MAC})^{(122)}$ posibilitó la puesta en marcha de un vasto programa de investigación e intervención centrado en el concepto coping. Será ahora el estrés, en su variante etiológica como agente inductor del cáncer de mama ${ }^{(123)} \mathrm{o}$ en su variante funcional como estilo de afrontamiento 
que determina la adaptación del paciente, el elemento central del discurso y la práctica psico-oncológica. Bajo el supuesto que la experiencia de sufrir un cáncer puede ser abordada a través de estrategias que faciliten un negative o un positive adjustment ${ }^{(124)}$, se configura así un grupo de sujetos que atendiendo a su gestión disfuncional en términos conductuales y cognitivos es susceptible de ser incluido en psicoterapias destinas a modificar sus pautas de respuesta ante eventos adversos.

4. En 1957 LeShan $^{(125)}$ publicó un artículo donde afirmaba que la aparición de linfomas se asociaba a determinadas características de la psicobiografía del sujeto afecto. Iniciada en un trauma infantil y, tras diversos estadios, fijado un período caracterizado por la pérdida de relaciones, escasas habilidades sociales y una disminución de la actividad física y emocional, esta estructura psíquica favorecería el diagnóstico de la enfermedad de Hodgkin entre los ocho meses y los seis años una vez instaurada la etapa final. De alguna forma el cáncer se entendería como la estación término de una vida que ha configurado una psique que predispone al enfermar. Este énfasis en lo biográfico se ha visto favorecido por la reciente introducción de lo traumático no tanto desde una perspectiva etiológica, sino considerando que la vivencia de un cáncer puede entenderse como un trauma en sí mismo ${ }^{(126)}$. El potencial lesivo de lo oncológico, la necesidad de reconstruir las creencias básicas dañadas sobre las que sustentamos nuestra visión del Self, el Mundo y los Otros, facilita la inclusión de lo psicológico como búsqueda de sentido al cáncer dentro de un contexto biográfico que lo dote de significados adaptativos.

Lo que estas perspectivas tienen en común, lo que las unifica bajo un mismo pa- raguas de sentido, es que todas ellas hacen referencia e introducen no tanto una enfermedad o trastorno mental susceptible de ser abordado psicoterapéuticamente, sino que derivan a ese mundo paralelo del déficit, de lo carencial, de lo deteriorado, de lo mal construido, donde la actividad rehabilitadora gana fuerza frente a los planteamientos más curativos. En un estudio realizado por Gil et al. ${ }^{(127)}$ con una muestra de 400 pacientes oncológicos del Instituto Catalán de Oncología (ICO), solo 97 pacientes informaban de la presencia de sintomatología que cumpliera criterios de trastorno según DSM-IV y de ellos 75, un $77,3 \%$, fueron diagnosticados de trastorno adaptativo, una etiqueta discutida en tanto constituye un cajón de sastre para aquellas reacciones emocionales ligadas a un evento adverso difíciles de definir en términos psicopatológicos ${ }^{(128)}$. De esta forma, parece que la labor terapéutica de nuestros psico-oncólogos se centraría más en proporcionar estrategias de afrontamiento que faciliten la adaptación a la enfermedad, propiciar la expresión emocional, resignificar episodios biográficos dolorosos $\mathrm{O}$ generar procesos de crecimiento personal, actividades adscritas más al ámbito de lo carencial que a la atención de unos procesos psicopatológicos poco prevalentes en cáncer. En el marco del vasto proceso de desestigmatización iniciado a principios de la década de los 80' en USA, ¿qué sentido tiene una disciplina que como la psico-oncología se fundamenta en los estados deficitarios de las pacientes afectadas por cáncer?, ¿cómo conjugar la imagen positivizada de la superviviente connotándola al mismo tiempo de carencial?, ¿cómo, por ejemplo, una mujer tratada por un psicooncologo a consecuencia de sus dificultades de gestión emocional puede presentarse culturalmente como el paradigma de la maduración y crecimiento personal?. Esta potencial contradicción, que podría lastrar el afan desestigmatizador del activismo 
anticancer hegemónico, se atenúa desde dos perspectivas discursivas distintas pero complementarias:

1. Por un lado, inscribiendo la tarea terapéutica en el marco de las narraciones heroicas, relatos de cambio y transformación, propias de la supervivencia en cáncer. Así, como indicamos en apartados anteriores, el tradicional énfasis otorgado a los elementos constitucionales como el género o la personalidad en su papel etiológico del cáncer de mama se desplaza a otras variables de naturaleza más modificable, menos permanente, que pueden influir en el curso del trastorno. Se genera de esta forma la posibilidad que la paciente, mediante el consejo de uno de los múltiples manuales de autoayuda o bajo el asesoramiento de un psico-oncologo, inicie una trabajo introspectivo de cara a monitorizar sus sentimientos negativos, visualizar aspectos positivos de su vida, resignificar posibles traumas, mejorar sus estrategias de afrontamiento del estrés... todo un trabajo que constituye parte de los retos propuestos a la futura superviviente. Si antes el cáncer era entendido como el destino trágico de una existencia desgraciada o una constitución predisponente, ahora la enfermedad pasa a considerarse como una oportunidad de mejora si el sujeto es capaz de afrontar el reto de modificar aquellos aspectos disfuncionales de su mundo emocional con la ayuda y guía de un profesional de la psicología. Su éxito será la prueba más evidente de su fortaleza, de su tenacidad, de su autocontrol.

2. Por otra parte, toma sentido desde esta perspectiva los cambios acontecidos en la disciplina psico-oncológica durante los últimos años, unos cambios que bajo el paradigma de la psicología positiva ponen nuevo énfasis no ya en las carencias y déficits del paciente, sino en sus capacidades y tendencia innata a la auto-ealización ${ }^{(129)}$. Así, la tarea del psicólogo no pasaría tanto por restituir en lo posible una salud psíquica dañada por el cáncer, sino por ayudar al paciente a dar nueva forma a un material que, de hecho, siempre había estado presente en su interior de manera potencial. Esta labor, inscrita en el actual marco donde el pensamiento positivo y el desarrollo personal constituyen objetivos asumidos por buena parte de la población, resitúa a la paciente con cáncer de mama en una posición ventajosa en términos psicológicos; como consecuencia de su enfermedad, se ve empujada a realizar el proceso de automaduración y autoconocimiento que todos y cada uno de nosotros deberíamos Ilevar a cabo ${ }^{(130)}$. El cáncer, de esta forma, pierde su condición estigmatizante y se presenta como una oportunidad de cambio; el paciente que ha superado la enfermedad se despoja de sus representaciones en negativo y se transforma en uno de los prototipos de persona realizada culturalmente promocionado.

Esta concepción de lo psi en términos de tarea heroica autotransformativa y desarroIlo de las potencialidades internas permite ahora la presentación social de la paciente con cáncer despojada de sus antiguas vestiduras estigmatizantes. Si tradicionalmente el cáncer, como todas las enfermedades malditas, podía generar en los que lo padecían sentimientos de culpa y vergüenza asociados a una vivencia de contaminación y macula que los señalaba socialmente, ahora un nuevo discurso psico-oncológico los exculpa presentando a la superviviente como aquella mujer de gran fortaleza que al superar su cáncer ha podido actualizar todos sus recursos internos, superar sus traumas y madurar como persona.

Para ilustrar la contraparte subalterna y alternativa de este exitoso discurso deses- 
tigmatizador fomentado desde la psicología positiva resulta útil la experiencia narrada por Jackie Stacey ${ }^{(9)}$. Profesora universitaria, lesbiana y militante feminista, Stacey fue diagnosticada de un teratoma. En el tránsito por distintos dispositivos asistenciales su profesora de taichí le indicó que su cáncer era el producto de un desajuste energético producido por la contradicción existente entre sus deseos de ser madre y su elección de mantener relaciones sexuales solo con mujeres. Una indignada Stacey interpreta que la profesora le estaba culpabilizando de su enfermedad, es decir, que el cáncer era la consecuencia directa de su negativa a acostarse con compañeros masculinos. Y es que cuando desde lo psicológico se introducen variables de sujeto en la ecuación oncológica, ya sea como factores etiológicos o de pronósti$\mathrm{co}$, para las culturas subalternas quedan abiertas las puertas que autoresposabilizan de la enfermedad a la paciente. De esta forma, en el ámbito popular, el no haber superado la separación de los padres, haber sufrido maltrato por parte del marido o no manejar el estrés de forma adecuada pasan a constituir parte del arsenal cultural autoinculpatorio al que recurrir para explicar el diagnóstico de la enfermedad; no ser lo suficientemente positiva y perder la esperanza, preocuparse demasiado por las recaídas o reñir constantemente con la familia elementos que justifican la mala evolución del trastorno. Para Stacey la cuestión no radica en que la introducción psicológica del sujeto en su patología se realice de una manera estigmatizante o basándose en parámetros de positividad y autoensalzamiento. El problema para esta autora subyace en la permanente tendencia de psicologizar una enfermedad que como el cáncer es para ella, como para Sontag, solamente un problema biológico, orgánico, médico; el sujeto, en su conformación y biografía, no tiene nada que ver con su patología oncológica, la psicología y el cáncer son dos universos que transcurren en paralelo sin ningún punto de contacto. En todo caso y desde esta perspectiva, el papel del psicólogo no debería ir más allá de proporcionar soporte emocional a las pacientes desde una posición cálida, incondicional y empática, un rol que desde las culturas feministas-lésbicas entienden pueden realizar eficazmente los grupos de autoayuda ${ }^{(7)}$.

\section{DISCUSIÓN. HEGEMONÍA Y SENTIDO COMÚN}

A más de treinta años vista continua activo el debate generado a inicios de la década de los $80^{\prime}$, posiblemente vinculado a la reacción que en la comunidad gay propició la detección de los primeros casos de $\mathrm{VIH} / \mathrm{SIDA}$, donde se manifestó la presencia de amplios colectivos discriminados y estigmatizados tras haber sido diagnosticados de determinadas patologías. Como indica Susan Sontag en su ensayo La enfermedad como metáfora ${ }^{(45)}$, entre este conjunto de enfermedades oscuras el cáncer ha ocupado siempre un lugar preeminente. Compañero de la lepra, la sífilis, la peste o la tuberculosis, el cáncer ha sido tradicionalmente representado como la más terrible de las plagas, una sentencia que producía un sufrimiento inenarrable y hacía aconsejable el aislamiento-ocultación de las personas que lo padecían en un gesto que las excluía de la comunidad. Desde la vivencia de esta realidad estigmatizada, en la primavera de 1991, entre el colectivo de activistas norteamericanas se acordó que su situación como afectas de cáncer de mama había llegado a límites difíciles de tolerar que reclamaban de una acción radical y decidida de las autoridades federales. Consenso pero frágil y etéreo dado que la ya potente Susan G. Komen Foundation, nacida en los neoliberales estados del sur y con una fuerte implantación en toda el área central de los EUA, rechazó sumarse 
a un movimiento reivindicativo planteado en términos de confrontación directa contra la administración sanitaria, el colectivo médico y la industria farmacéutica-aseguradora americana. Esta ruptura generada desde la perspectiva pink ribbon ha marcado y marca todavía la historia cultural y la experiencia individual de muchas mujeres diagnosticadas de cáncer.

De esta forma, lo que en un origen se planteó como un problema social centrado en la supuesta discriminación que sufrían las mujeres con cáncer de mama respecto a otros colectivos se ha transformado en un gran movimiento desestigmatizador. Si a principios de los 90' las cuestiones reivindicadas desde el activismo anticáncer se centraban en la desproporción del gasto militar respecto al sanitario, las dificultades de acceso de determinados colectivos de mujeres a los programas de prevención, la desregulación de las políticas ambientales o la crítica a las multinacionales farmacéuticas respecto al acceso restringido a los ensayos clínicos, en la actualidad la cuestión se plantea como un déficit de concienciación respecto al problema del cáncer y la necesidad de un cambio en las representaciones sociales del enfermar oncológico. Desestigmatizar es la consigna; toda práctica o discurso en el mundo del cáncer adquirirá validez y legitimidad en tanto se ciña a este objetivo. Para ello, en este nuevo paradigma de la cultura pink ribbon y según nuestra propuesta de decálogo descriptivo:

1. Lo que antes permanecía oculto ahora debe hacerse visible con objeto de sensibilizar a la opinión pública respecto al grave problema que supone el cáncer. Presentado en forma epidémica y medicalizada, adscrito a metáforas bélicas que reclaman la participación de toda una comunidad afectada en términos de riesgo, el cáncer de mama antes experimentado como una patología vergonzante y culposa constituye ahora una cuestión ampliamente visualizada. Atrás queda la lógica normalizadora que obligaba a las mujeres con mastectomía intentar ocultar su condición de ex-pacientes oncológicas, condenándolas al silencio y al aislamiento; campañas de solidaridad en medios de comunicación, entrevistas a personajes famosos diagnosticados de cáncer que nos relatan su experiencia, concentraciones públicas masivas como muestra de apoyo... la desestigmatización del cáncer corre en paralelo a la generación de marcos donde pueda ser ampliamente visualizado.

2. Lo que antes se calificaba como negativo ahora se debe positivizar con objeto de dar nuevo valor a aquellas mujeres diagnosticadas de cáncer. La estrategia pasaría no tanto por negar el sufrimiento y dolor asociado a la experiencia oncológica, sino por resignificar la vivencia de enfermar como una oportunidad de cambio y transformación donde los afectos salen reforzados en términos de maduración personal. Superar la enfermedad implicaría, desde esta perspectiva y bajo la etiqueta de identidad de superviviente, dotar al self no de los atributos propios de la normalidad, sino dibujarlo y presentarlo socialmente bajo los parámetros de excepcionalidad positivizada espontáneamente generados tras "vencer al cáncer".

La construcción de un cáncer de mama vinculado a la positivización del self constituiría a nuestro entender el eje central por el que transita el proceso de desestigmatización defendido desde la cultura hegemónica del lazo rosa. La capacidad de la mujer con cáncer por controlar su mundo emocional manifestando esperanza y optimismo; la fortaleza probada al superar la más terrible de las pruebas; los beneficios que en forma de crecimiento personal comportan el diagnóstico de la enferme- 
dad; una espiritualidad incrementada que le permite conocer que lo es importante y lo que es superfluo en la existencia; una empatía que fomenta la comprensión y compasión del sufrimiento de los demás... todos estos elementos giran en torno a la idea central que sostiene buena parte de los discursos socialmente promovidos en torno al cáncer: que la enfermedad ha dejado de ser motivo de estigma y vergüenza, que el cáncer empieza a hablar ahora sobre los aspectos más positivos de nosotros mismos. Y lo hace con tal fuerza que, aplicando el marco conceptual propuesto por Gramsci, los discursos y las prácticas pink ribbon pueden Ilegar a adquirir naturaleza hegemónica, es decir, pueden llegar a imposibilitar entender el cáncer de una manera distinta. El pensamiento hegemónico, por definición, intenta desvincularse de las circunstancias históricas en que se ha desarrollado, ocultar los supuestos ideológicos sobre los que se sustenta, para presentarse como una cuestión de puro y simple sentido común... ¿y quién es capaz de cuestionarse, criticar, plantear alternativas o no adscribirse a lo que socialmente es entendido como un consenso basado en la lógica más neutra y la evidencia más palmaria? El pensamiento hegemónico, por definición, tiende a anular cualquier otra posibilidad de pensar y pensarnos de maneras distintas, a crear falsas apariencias de unanimidad. El objetivo explicito de esta reflexión teórica radica, justamente, en analizar las bases históricas e ideológicos sobre las que se sostiene un determinado discurso en torno el cáncer que, en determinados ámbitos, ha adquirido o está empezando a adquirir una naturaleza incuestionada e indiscutible que hace ya difícil abordar la complejidad de lo oncológico desde perspectivas múltiples. Pese a la ausencia de estudios antropológicos en nuestro país conjeturamos que, a partir de las investigaciones realizadas en otros entornos culturales y de la bibliografía consultada, las pretensiones hegemónicas de consenso asociadas a las organizaciones activistas del lazo rosa pueden generar rechazos y resistencias hacia esta comunidad narrante a partir de los siguientes supuestos:

1. La cultura del lazo rosa, nacida en el entorno conservador y neoliberal norteamericano de los estados del sur, presenta un claro sesgo ideológico. Defiende una noción de feminidad que, al primar valores asociados a la familia tradicional, el papel esencialmente reproductivo de la mujer, el atractivo como ideal estético o la función cuidadora como rol femenino, segregan del activismo anticáncer a aquellas mujeres, como las feministas o lesbianas, ideológicamente alejadas de estas concepciones.

2. Presenta sesgos de autoensalzamiento, es decir, tiende a representar socialmente a la persona que ha superado un cáncer con unas características que la definen como mujer excepcional. Una gran fortaleza interna, una esperanza a toda prueba, un optimismo contumaz y un coraje ejemplar dibujan la figura de una superviviente que segrega a aquellas mujeres que pretenden ser consideradas en términos de total normalidad y que no desean adscriben a las narrativas heroicas.

3. Al centrarse en los factores de riesgo y los estilos de vida saludable individualizan el problema del cáncer de mama considerándolo en parte como algo relativamente controlable que depende de las elecciones que realiza cada sujeto sobre cómo quiere vivir su vida. Esta individualización, llevada a su extremo, corre el peligro de culpar y responsabilizar o las pacientes de su enfermedad. Se segrega de esta forma a todos aquellos colectivos de activistas que ponen énfasis en los aspectos sociales y culturales del enfermar, es 
decir, que consideran el cáncer de mama como una enfermedad surgida en un entorno económico y vital que, mediante la injusticia y la discriminación genérica, facilita la expansión de la patología.

4. Las organizaciones del lazo rosa pueden Ilegar a presentar una vivencia del cáncer de mama que tiene poco que ver con la realidad del enfermar. Al focalizar su atención en la necesidad de positivizar la experiencia y considerarla como una oportunidad para madurar personalmente, en la profesionalidad de los equipos médicos o en el gran soporte ofrecido por el entorno familiar, se segrega a aquellos colectivos de mujeres afectas que entiende su cáncer como una experiencia de sufrimiento inútil e injusto, que reclaman un entorno asistencial más humanizado o manifiestan quejas sobre la incapacidad de su entorno por entender su difícil situación.

5. Las manifestaciones públicas realizadas desde la perspectiva pink ribbon se llevan a cabo mayoritariamente desde una posición emocional donde prima el ánimo expansivo, la sensación de alegría y la intención festiva. Algunas mujeres se sienten segregadas de este tipo de actos en tanto el cáncer de mama, la realidad dura y sufriente que comporta la muerte de algunas de ellas, no justifica ningún tipo de celebración. Las amplias sonrisas, abrazos indiscriminados, saltos y cabriolas propias de las carreras populares no reflejarían en ningún caso el dolor asociado a diagnóstico de un cáncer.

6. La función de recaudación de fondos consustancial a las organizaciones del lazo rosa involucra en la investigación médica a toda una serie de empresas y multinacionales que, en algunos casos, pueden entender el cáncer de mama como una buena estrategia de marke- ting para fidelizar a sus clientes y mejorar la imagen de su marca. Se segrega así a aquellos colectivos de afectadas que, dada la seriedad del problema, entienden que la financiación y gestión de las políticas anticáncer deben realizarse a través de mecanismos públicos y comunitarios que aseguren la atención de las necesidades de las pacientes sin inmiscuir a los grandes complejos industriales.

Planteada así la cuestión cabe preguntarnos los motivos por los que las mujeres afectadas por un cáncer, de un tiempo a esta parte, parecen prestar especial atención a su apariencia física como elemento central de su vivencia oncológica. El auge de talleres de cosmética, la insistencia en que el cáncer no es incompatible con la belleza, la profusión de productos del mundo de la moda específicos para mujeres afectas, las exposiciones fotográficas de estética glamurosa con modelos en quimioterapia, la percepción del atractivo físico como signo de haber superado la enfermedad... todo un conjunto de elementos dan pie a pensar que mantener una apariencia saludable y agradable ha pasado a constituir uno de los imperativos que definen una adecuada adaptación al proceso de enfermar por cáncer. Es una cuestión planteada en términos de sentido común. Si la paciente conserva su buena apariencia, por un lado, ello repercutirá en términos de mejor "autoestima" y un sentirse emocionalmente más a gusto con su aspecto; por otro lado, esta imagen cuidada informará a los otros que mantiene el ánimo, la positividad y el coraje suficiente para luchar contra la enfermedad. Pero asumiendo sin dudar todas las consecuencias positivas derivadas de mantener una buena imagen, desde posiciones de activismo feminista se plantea... ¿por qué motivo circunscribir el atractivo físico al ámbito exclusivamente femenino?, ¿no podrían los hombres aprovecharse de todos 
estos abordajes cosméticos?, ¿porque no se generan programas donde pacientes con cáncer de próstata aprendieran a cuidar de su imagen, o montar exposiciones de atractivos varones afectados por un cáncer de pulmón? Y es que lo que aparentemente se presenta como una cuestión de sentido común, las bondades y beneficios derivados de mantener un buen aspecto físico, para las organizaciones activistas feministas está teñido de indudables componentes ideológicos que definen una determinada manera de entender la feminidad. Reproduciendo estereotipos, mientras que a las mujeres con cáncer se las insta y premia socialmente por estar guapas y mantener su atractivo pese al diagnóstico de cáncer, los varones dan muestra de su coraje y fortaleza acudiendo a cumplir sus obligaciones laborales a pesar de los efectos adversos del tratamiento.

Sobre la respuesta a decenas de preguntas similares a las planteadas en el titulo de este ensayo se está construyendo un amplio consenso en torno a la experiencia de padecer un cáncer, un acuerdo social donde en innumerables ocasiones se repiten los mismos argumentos con el beneplácito de todos. Entendemos que el consenso, en este caso concreto de lo oncológico, debería nacer de la puesta en común de visiones diversas, de opiniones divergentes, y no de la mayoritaria adscripción a unos postulados que se presentan sin alternativa posible, como algo propio del sentido común. Lo sorprendente en cáncer de mama no radica tan solo en la ausencia de una articulación de múltiples prácticas y discursos, sino en que pensar y actuar la experiencia de sufrir la enfermedad de maneras distintas no se inscribe tanto en el ámbito de las elecciones personales, lo cual podría ser discutido y analizado, sino en el terreno de lo raro y extravagante, lo que imposibilita todo diálogo. En suma, ¿por qué en una sociedad plural y compleja como la nuestra se configuran ámbitos donde la pluralidad y complejidad no se manifiestan? Intentar dar respuesta a esta cuestión ha constituido el eje del presente trabajo; en la idea que un pensamiento único es potencialmente un pensamiento empobrecido, la posibilidad de problematizar lo que socialmente se presenta como evidente abre las puertas a reflexiones críticas que podrían ayudar a las pacientes con cáncer a experimentar su enfermedad de forma más autoconsciente y creativa. Generar marcos y encuentros donde las pacientes con cáncer puedan, libres en lo posible de las influencias sociales que determinan la "forma correcta" de experimentar la enfermedad, dar un sentido personal a sus vivencias podría constituir un objetivo terapéutico a valorar por los equipos asistenciales. Oponer, en definitiva, la libre elección de la experiencia a las formas determinadas por un pensamiento hegemónico presentando como presunto sentido común.

\section{Agradecimientos:}

El presente estudio ha sido posible gracias al soporte de: Asociación Española Contra el Cáncer, Junta de Barcelona de la Asociación Española Contra el Cáncer, FIS PI10/00748.

\section{REFERENCIAS BIBLIOGRÁFICAS}

1. National Cancer Institute (NCI). National Cancer Act of 1971 (n. d.) En línea [Acceso 16 de junio de 1912]. Doisonible en: http://dtp.nci.nih.gov/timeline/noflash/ milestones/M4 Nixon.htm

2. Kushner R. Breast cancer: A personal history and an investigative report. New York: Harcourt Brace Jovanovich, 1975.

3. Lerner BH. The breast cancer wars. Hope, fear, and the pursuit of a cure in twentiethcentury America. New York: Oxford University, 2001.

4. Lerner BH. III patient, public activist: Rose Kushner's attack on breast cancer chemotherapy. Bull Hist Med 2007; 8:224240. Doi: 10.1353/bhm.2007.0006 
5. Casamayou $\mathrm{MH}$. The politics of breast cancer. Washintong DC: Georgetown Univ. Press, 2001.

6. Klawiter M. Breast cancer in two regimes: The impact of social movements on illness experience. Sociol Health Illness 2004; 26(6):845-74. Doi:10.1111/j.14679566.2004.421_1.x

7. Klawiter M. The biopolitics of breast cancer. Changing cultures of disease and activism. Minneapolis: University of Minnesota Press, 2008.

8. Sulik GA. Pink ribbon blues. How breast cancer culture undermines women's health. New York: Oxford Univ. Press, 2011.

9. Stacey J. Teratologies. A cultural study of cancer. London: Routledge, 1997.

10. Crehan K. Gramsci, cultura y antropología. Barcelona: Bellaterra, 2004.

11. Rodríguez Prieto R, Seco Martínez JM. Hegemonía y democracia en el siglo XXI: ¿Por qué Gramsci? Cuadernos electronicos de filosofia del derecho 2007, 5.

12. Conrad P. Medicalization and social control. Ann Rev Sociol 1992;18:211.

13. Illich I. Medical nemesis. New York: Random House, 1976.

14. Foucault M. La vida de los hombres infames. Buenos Aires: Altamira, 1996

15. Foucault M. Vigilar y castigar. Madrid: Siglo XXI, 1986.

16. Pinell, $\mathrm{P}$ y Brossat M.. The birth of cancer policies in France. Sociolo Health and IIIness 1988;10(4):579-607.

17. Aronowitz A. Unnatural history. Breast cancer and American society. New York: Cambridge Univ. Press, 2007.

18. Izquierdo A, Gispert R, Saladie F, Espinàs JA. Análisis de la incidencia, la supervivencia y la mortalidad según las principales localizaciones tumorales, 19852019: cáncer de mama. Med Clin 2008; 131(Suppl.1): 50-2.

19. Pollán $M$, García-Mendizabal MJ, PerézGómez B, Aragonés N, Lope V, Pastor R. Ramis $R$, et al. Situación epidemiológica del cáncer de mama en España. Psicooncología 2007; 4(2-3):231-48.

20. Lerner $\mathrm{BH}$. Inventing a curable disease: Historical perspectives on breast cancer. En: Kasper AS, Ferguson SJ, editors. Breast cancer. Society shapes an epidemic. New York: Palgrave, 2000; p. 25-49.
21. Tritter JQ, Calnan M. Cancer as a chronic illness? Reconsidering categorization and exploring experience. Eur J Cancer Care 2002; 11:161-5. Doi: 10.1046/j.13652354.2002.00345.x

22. FECMA. Manifiesto 2011. [en línea] 2011 [acceso 5 de enero de 2013]. Dinsponible en: http://fecma.vinagrero.es/manifiesto. aspx

23. Hansen HP, Tjornhoj-Thomsen T. Cancer rehabilitation in Denmark: The growth of a new narrative. Med Anthropol Q 2008; 22(4): 360-80. Doi:10.1111/j.15481387.2008.00035.x

24. Ferro T, Borràs, JM. Una bola de nieve está creciendo en los servicios sanitarios: los pacientes supervivientes de cáncer. Gac Sanit 2011: 25:240-5. Doi: 10.1016/j.gaceta.2010.12.002

25. Rowland JH, Hewitt M, Ganz PA. Cancer survivorship: A new challenge in delivering quality cancer care. J Clin Oncol 2006; 24(32):5101-5104.

26. National Coaliton for Cancer Survivorship. our mission. [en línea] 2013 [acceso 5 de enero de 2013] Disponible en: http://www.canceradvocacy.org/about-us/ our-mission/.

27. Robertson A. Embodying risk, embodying political rationality: women's accounts of risks for breast cancer. Health, Risk Society 2000; 2(2):219-235. Doi: 10.1080/713670161

28. Blackwood M, Weber B. BRCA1 and BRCA2: from molecular genetics to clinical medicine. J Clin Oncol 1988; 16(5):196977.

29. Vaz P, Bruno F. Types of self-surveillance: From abnormality to individuals "at risk". Surveillance Society 2003; 1(3):272-91.

30. Delumeau, J. El miedo en Occidente. Madrid: Taurus, 1989.

31. Cuadrada, C. El Ilibre de la pesta. Barcelona: Rafael Dalmau, 2012.

32. Defoe, D. Diario del año de la peste. Barcelona: Seix Barral, 1996.

33. Arrizabalaga J. La peste negra de 1348: los origenes de la construccion como enfermedad de una calamidad social. Dynamis. Acta hispanica ad medicinae scientiarumque historiam Ilustrandam 1991; 11:73117.

34. Foucault M. Historia de la locura en época clásica. Madrid: FCE, 1985 
35. Paterson JT. The dread disease. Cancer and modern american culture. Cambridge: Harvard University Press, 1987.

36. Rosemberg CE. Pathologies of progress: The idea of civilization as risk. Bull Hist Med 1996; 72(4):714

37. Lantz PM, Booth KM. The social construction of breast cancer epidemic. Soc Sci Med 1998; 46(7):907-18. Doi: 10.1016/ S0277-9536(97)00218-9,

38. Revista Pronto, $\mathrm{n}^{\mathrm{a}}$ 2110, 13-10-2012.

39. Agamben G. Homo sacer. El poder soberano y la nuda vida. Valencia: Pretextos, 1998.

40. Stallaert C. Ni una gota de sangre impura. La España inquisitorial y la Alemania nazi cara a cara. Barcelona: Galaxia Gutenbert, 2006.

41. Abel EK. From exclusion to expulsion: Mexicans and tuberculosis control in Los Angeles, 1914-1940. Bull Hist Medicine 2003; 77(4):823-49

42. Stuber J, Galea S, Link BG. Stigma and smoking: the consequences of our good intentions. Soc Serv Rev 2009; 83(4):586610. Doi:10.1086/650349

43. Proctor RN. The nazi war on cancer. Princeton: Princeton Univ. Press, 1999.

44. Fernandez J. The mission of metaphor in expressive culture. Curr Anthropol 1974; 15(2): 119-145.

45. Sontag S. La malaltia com a metàfora. Barcelona: Empúries, 1997.

46. Giraldo-Mora CV. Persistencia de las representaciones sociales el cáncer de mama. Rev Salud Pública 2009; 11(4):514-25.

47. Nolte K. Carninoma Uteri and 'sexual debaucery'. Morality, cancer and gender in the nineteenth century. Soc Hist Med 2008; 21(1): 31-46. Doi: 10.1093/shm/ hkm116

48. Salcedo Fidalgo H. Representaciones sociales y metaforas del cáncer en los siglos XVII y XVIII: una antologia de lugares Comunes. Antipoda 2008; 6: 199-213.

49. Taylor T. 'Purgatory on Earth': An account of breast cancer from nineteenth-century France. Soc Hist Med 1998; 11(3):381-402.

50. DiGiacomo, SM. Metaphor as illness: Postmodern dilemmas in the representation of body mind and disorder. Med Anthropol 1992; 14: 109-37.

51. Scheper-Hughes N, Lock MM. Speaking "truth" to illness: Metaphors, reification, and pedagogy for patients. Med Anthropol Quat 1986; 17(5):137-9.
52. Potts L K Ideologies of breast cancer: Feminist perspectives. London: Macmillan, 2000.

53. Leopold E. A darker ribbon. Breast cancer, women, and their doctors in the twentieth century. Boston: Beacon Press, 1999.

54. Clow B. Who's afraid of Susan Sontag? or, the myths and metaphors of cancer reconsidered. Soc Hist Medi 2001; 14(2):293-312.

55. Lupton D. Feminity, responsibility, and the technological imperative: Discourses on breast cancer in the Australian press. Inter J Health Serv 1994; 24(1):73-89.

56. Anderson WB. "We can do it": a study of the Women's Field Army public relations efforts. Public Relations Rev 2004; 30(2):187-96. Doi: 10.1016/j.pubrev.2004.02.003

57. Clarke JN, Everest MM. Cancer in the mass print media: Fear, uncertainty and the medical model. Soc Sci Med 2006; 62:2591-600. Doi: 10.1016/j.socscimed.2005.11.021

58. Seale C. Sporting cancer: Struggle language in news reports of people with cancer. Sociol Health III 2001; 23(3):308-29.

59. Kristeva J. Powers of horror. An essay on abjection. New York: Columbia Univ. Press, 1982

60. Douglas M. Pureza y peligro: análisis de los conceptos de contaminación y tabú. Madrid: Siglo XXI, 2000.

61. Wiess M. Signifying the pandemics: metaphors of AIDS, cancer, and heart disease. Med Anthropol Quat 1997; 11(4):456-76.

62. King S. Pink Ribbons, Inc. Minneapolis: University of Minnesota Press, 2006.

63. Lubitow A, Davis M (2011) Pastel injustice: The corporate use of pinkwashing for profit. Environmental Justice 2011; 4(2):139-44. Doi: 10.1089/env.2010.0026

64. Breast Cancer Action. www.bcaction.org

65. Rieff D. Un mar de muerte. Barcelona: Debate, 2008.

66. Germà JR. El cáncer se cura. Barcelona: Booket, 2008.

67. Wright JR. The 1917 New York biopsy controversy: A question of surgical incision and the promotion of metastasis. Bull Hist Med 1988; 62:546-62.

68. Lerner, BH. The breast cancer wars. Hope, fear, and the pursuit of a cure in twentiethcentury America. New York: Oxford Univ. Press, 2001. 
69. Medina Doménech RM. Scientific rhetoric in the consolidation of a therapeutic monopoly. Radiotherapy in Spain 1895-1936. Socl Hist Med 2007; 10(1):221-42.

70. Keating P, Cambrosio A. Cancer clinical trials: The emergence and development of a new style of practice. Bull Hist Med 2007; 81:197-223. Doi: 10.1353/ bhm.2007.0003

71. Dyer KE. From cancer to sexually transmitted infection: Explorations of social stigma among cervical cancer survivors. Human Organization 2010; 69(4):321-30.

72. Jasen P. From the "Silent Killer" to "Whispering Desease": Ovarian cancer and the uses of metaphor. Med Hist 2009; 53(4):489512. Doi: 10.1017/S0025727300000521

73. Menéndez EL. El Modelo Médico Hegemónico: transacciones y alternativas hacia una fundamentación teórica del modelo de autoatención en salud. Arxiu d’Etnografia de Catalunya 1984; 3: 85-119.

74. Menéndez EL. Intencionalidad, experiencia y función: la articulación de los saberes médicos. Rev Antropol Social 2005; 14; 33-69.

75. Burnham JC. The death of the sick role. Soc Hist Med 2012; 25(4):761-76.

76. DiGiacomo SM. The case: A narrative deconstruction of "diagnostic delay". Second Opinion 1995; 20(4):21-35.

77. Davis D. The secret history of the war of cancer. New York: Bassic Books, 2007.

78. Carson R. Silent Spring. Boston: Houghton Mifflin Company, 2002.

79. Ferguson SJ. Deformities and diseased: The medicalitaion of women's breast. En: Kasper AS, Ferguson SJ, editors. Breast cancer. Society shapes an epidemic. New York: Palgrave 2000. p. 51-86.

80. Brown P, Zavestoski, S, McCormick S, Mayer B, Morello-Frosch R, Altmant, R. Embodied health movements: New approaches to social movements in health. Sociol Health Illness 2004; 26(1):50-80. Doi: 10.1111/j.1467-9566.2004.00378.x

81. Olsen O, Gotzsche PC. Cochrane review on screening for breast cancer with mammography. Lancet 2001; 358:1340-2. Doi: 10.1016/S0140-6736(01)06449-2

82. Borràs JM, Espinàs JA, Castells X. La evidencia del cribado del cáncer de mama: la historia continua. Gac Sanit 2003;17(3):24955. Doi: 10.1157/13049287
83. Jasen P. Breast cancer and the language of risk, 1750-1950. Soc Hist Med 2002 15(1):17-43. /10.1093/shm/15.1.17

84. Aronowitz RA Do not delay: Breast cancer and time, 1900-1970. Milbank Q 2001; 79(3):355-86.

85. Odgen J. Psychosicial theory and the creation of the risky self. Soc Sci Med 1995; 40(3): 409-415.

86. FORCE http://www.facingourrisk.org/

87. Wilkinson S. Mujeres feministas en lucha contra el cáncer de mama: lo personal y lo político. Anuario de Psicología 2008; 39(1): 23-39.

88. Petersen A, Bunton R, editors. Foucault, health and medicine. New York: Routledge, 1997.

89. Cantor D. Introduction: Cancer control and prevention in the Twentieth century. Bull Hist Med 2007; 81: 1-38.

90. Bell K. Cancer survivorship, mor(t)ality and lifestyle discourses on cancer prevention. Sociol Health III 2010; 32(2): 349-364.

91. Yadlon S. Skinny women and good mothers: The rhetoric of risk control, and culpability in the production of knowledge about breast cancer. Feminist Studies 1997; 23(3): 645-677.

92. Armstrong D. The rise of surveillance medicine. Sociol Health III 1995; 17(3): 393404.

93. Meyer D. The positive thinkers. Middleton, Connecticut: Wesleyan Univ. Press, 1988.

94. Satter B. Each mind a kingkom. American women, sexual purity and the New Thought Movement. 1875-1920. England: Univ. of California Press, 1999.

95. Cabanas Diaz E, Sanchez Gonzalez, JC. Las raíces de la psicología positiva. Papeles del Psicologo 2012; 33(3):172-82.

96. Ehrenreich B. Sonrie o muere. La trampa del pensamiento positivo. Madrid: Turner, 2011.

97. Harrington A. The cure within. A history of mind body medicine. New York: W. W. Norton, 2008.

98. Byrne R. El secreto. Barcelona: Urano, 2007.

99. Tedeschi RG y Calhoun LG. Trauma and transformation: Growing in the aftermath of suffering. Thousand Oaks: Sage, 1995.

100. Thornton AA, Perez MA. Posttraumatic growth in prostate cancer survivors and their partners. Psychooncology 2006; 15:285-96. Doi: 10.1002/pon.953 
101. Ehrenreich B. Welcome to Cancerland. Harper's Magazine, nov. 2001.

102. De Raeve L. Positive thinking and moral opression cancer care. Eur J Cancer Care 1997; 6:249-56.

103. Mullan F. Seasons of survival: Reflections of physician with cancer. $N$ Engl J Med 1985; 313:270-2

104. Frank AW. The wounded storyteller. Chicago: University of Chicago Press, 1995.

105. Gubar S. Not a cancer survivor. Wellblogs.nytimes. Com /2012/09/06/not-acancer-survivor

106. Bauman Z. Modernidad y Holocausto. Madrid: Sequitur, 2006.

107. Deimling GT, Kahana B, Schumacher J. Life threatening illness: the transition from victim to survivor. J Aging Identity 1997; 2(3):165-86.

108. Deimling GT, Bowman KF, Wagner LJ. Cancer survivorship and identity among long-term survivors. Cancer Investigation 2007: 25(8); 758-65. Doi: 10.1080/07357900600896323

109. Park CL, Zlateva I, Blank TO. Self-identity after cancer: "survivor", "victim", "patient" and "person with cancer". J Gen Inter Med 2009; 24 (Suppl. 2): 430-5. Doi: 10.1007/ s11606-009-0993-x

110. Coreil J, Wilke J, Pintado I. Cultural models of illness and recovery in breast cancer support groups. Qual Health Res 2004; 14(7):905-23. Doi: $10.1177 / 1049732304266656$

111. Kaiser K. The meaning of the survivor identity for women with breast cancer. Soc Sci Med 2008; 67: 79-87. Doi: 10.1016/j. socscimed.2008.03.036

112. Geremek B. La piedad y la horca. Madrid: Alianza, 1989.

113. Yalom M. Historia del pecho. Barcelona: Tusquets, 1997.

114. Holleb Al. Two decades of Reach to Recovery: A tribute to the volunteers. CA: A cancer journal for clinicians 2008; 40(1):5-7. Doi: 10.3322/canjclin.40.1.5

115. Lorde A. The cancer journals. San Francisco: Aunt Lute Books, 1997.

116. Carr K. Crazy sexy cancer survivor. Guilford, Connecticut: The Globe Pequot Press, 2008.

117. Foucault M. Los anormales. Madrid: Akal, 2001.

118. Morris T, Greer S, Pettingale KW, Watson M. Patterns of expressing anger and their psychological correlates in women with breast cancer. J Psychosom Res 1981; 25:111-7.

119. Jasen P. Breast cancer and the language of risk, 1750-1950. Soc Hist Med 2002; 15(1):17-43.

120. Lawlor C, Suzuki A. The disease of the Self: Representing consumption, 17001830. Bull Hist Med 2000; 74:458-94.

121. Stanton $\mathrm{AL}$, Danoff-Burg $\mathrm{S}$, Cameron $\mathrm{CL}$, Bishop M, Collins CA, Kirk SB, Sworoski LA. Emotionally expressive coping predicts psychological and physical adjustment to breast cancer. J Consul Clin Psychol 2000; 68(5):875-82.

122. Watson M, Greer S, Young J, Inayat Q, Burgues C, Robertson C. Development of a questionnaire measure of adjustment to cancer. The MAC scale. Psychol Med 1988; 18:203-9.

123. Lavinas MC, Lessa B, Freitas JJ, Frassinetti P, Fernandes C, Galvao C, Carvalho AF. Association between stress and breast cancer: A meta-analysis. Cad. Saúde Publica 2009; 25 (Suppl. 3): 453-463.

124. Watson M, Homewood J, Haviland J. Coping response and survival in breast cancer patients: A new analysis. Stress Health 2012; 28(5):376-80. Doi: 10.1002/ smi.2459

125. LeShan LL. A psychosomatic hypothesis concerning the etiology of Hodgkin's disease. Psychol Report 1957; 3:565-75.

126. Sumalla EC, Ochoa C, Blanco I. Posttraumatic growth in cancer: Reality or Illusion?. Clin Psychol Rev 2009; 29:24-33. Doi: 10.1016/j.cpr.2008.09.006

127. Gil FL, Costa G, Peréz JP, Salemero M, Sanchéz N, Sirgo N. Adaptación psicológica y prevalencia de trastornos mentales en pacientes con cáncer. Med Clin 2008; 130(3):90-92.

128. Casey P, Baile S. Adjusment disorders: The state of art. World Psychiatry 2011; 10(1):11-8.

129. Ochoa C, Sumalla EC, Maté J, Castejón V, Rodríguez A, Blanco I, Gil F. Psicoterapia positiva grupal en cáncer. Hacia una atención psicosocial integral del superviviente en cáncer. Psicooncologia 2010; 7(1):734.

130. Pérez-Álvarez M. La psicología positiva: magia simpática. Pap Psicol 2012; 33(3):183-201. 